\title{
9/11 UND DIE Folgen IN DER POPMUSIK IV. EINE AUSWAHLDISKOGRAPHIE
}

\author{
Thomas Phleps
}

Die nachfolgende Diskographie bietet nur einen kleinen Ausschnitt aus der 9/11 und die Folgen betreffenden Musikproduktion. Nur in ganz geringem Umfang bspw. sind Songs der vor allem von Amateuren bis Semiprofis bestückten Musikportale für den kostenlosen Download von MP3s oder anderen Audioformaten (wie MP3.com, luma.com, Soundclick.com oder Besonic. com) aufgeführt - hier zeigt sich am deutlichsten die Flüchtigkeit des Internets, da zahlreiche dieser immerhin rund 1300 Songs (und so manche der unten aufgeführten) u.a. durch den Wechsel der Besitzverhältnisse an der Domain MP3.com, dem größten dieser Portale, über ihre einstigen Adressen nicht mehr abrufbar sind (vgl. S. 64). Diese mitunter arg amateurhaften Musikproduktionen wurden vor allem in den ersten Monaten nach 9/11 und im Umfeld des Afghanistankrieges ins Netz gestellt; zu Zeiten der sich zuspitzenden Irakkrise resp. der US-Kriegsvorbereitungen, im Februar/ März 2003 also entwickelte sich das WorldWideWeb zu einer alternativen Publikationsmöglichkeit auch für die Profis, die ihre engagierten Protestsongs unzensiert, ohne kommerziellen Hintergrund und vorzugsweise im MP3-Format allen Interessierten über ihre eigenen Homepages und - sehr schnell - zahlreiche Musikportale meist im MP3-Format frei zugänglich machten.

Die diskographischen Unterteilungen in Tribute, Pro War oder Anti War Songs dienen eher der Orientierung und wollen nicht die Songs in Schubladen ablegen. Nicht selten auch sind diese Einordnungen weniger vom Song selbst als den ihn umgebenden Zuschreibungen bestimmt. Die diskographischen Angaben sortieren sich wie folgt:

Interpret(en): Song- resp. Albumtitel (Tonträgerformat, Erscheinungsdatum resp. Kompositions- oder Aufnahmedatum) [Genre] [Internetadresse zu Musik und/oder Text oder auch nur zu weiterführenden Informationen; entfällt bei CD-Veröffentlichungen bekannter Interpreten]. 
Das Erscheinungsdatum 2001 bezieht sich selbstverständlich, wenn nicht anders vermerkt, auf die Zeit nach dem 11. September. Die Genrezuweisungen sind in der Regel holzschnittartig vorgenommen (Pop, Rock, Folk, Country, HipHop), speziellere beruhen auf von den Interpreten selbst angezeigten Zuweisungen.

\section{September 2001 - Dezember 2002 (9/11, Afghanistankrieg...)}

\subsection{Songs zu $9 / 11$}

Renae Angeroth: »Another Day« (mp3, 2002) [Pop] [http://www.beyond9-11.org/ angeroth.htm].

Anthrax: »Refuse To Be Denied« (CD We've Come For You All; Dez. 2002) [Metal].

Anti-C: »Buddy Buddy (Well, Well, Well, My Michel)« (MP3/Flash-Animation, 2002) [HipHop] [http://www.delcanton.com/cds/kaneandsalem.asp; http://www. ericblumrich.com/buddy.html].

Lisa Apatini: »Awakening« (MP3, 2001) [Folk] [http://www.lisaapatini.com].

Bon Jovi: »Undivided« (CD Bounce, Okt. 2002) [Pop].

Jeremy Borum: »Out Of Tune (MP3, 12.9.2001) [Folk] [http://jborum.crosswinds. net/description.html].

Jim Boyd: »September Morning / "One Day In America« (MP3, 2002) [Folk] [http://www.thunderwolfrecords.com/tribute.htm].

Busta Rhymes feat. Meka: »It Ain't Safe No More... « (CD It Ain't Safe No More, Nov. 2002) [HipHop].

Cam'Ron feat. Jay-Z \& Juelz Santana: »Welcome To New York« (CD Come Home With Me, Mai 2002) [HipHop].

Capleton: »Red Red Red« / »Guerilla Warfare« (CD Still Blazin, Feb. 2002) [Reggae].

The Cheapmunks (with Jack Asscroft): »Remember September 12th« (MP3, 2002) ['Humor<-Country] [http://www.bluecanyonproductions.com/satire.html].

Cher: »(This Is A) Song For The Lonely« (CD-Single/Video, März 2002) [Pop].

Cranberries: "New New York (CD Stars: The Best of 1992-2002, Sept. 2002) [Rock]. Wes Davey: »New York City Rain (On September 11th, God Cried Too)« (MP3, 20.11. 2001) [Folk] [http://artists.mp3s.com/artists/91/wes_davey.html].

Ethan Daniel Davidson: "September 11 - The Day The Universe Changed» (aufgen. 15.9.2001; CD The Bootleg Series Vol. 1, 2002) [Folk].

Garrett Dutton [von G. Love \& Special Sauce]: »On 9.11.01« (MP3, 2001; CD Various Artists: Bands For America, 13.11.2001) [Acoustic Rock].

Eminem: »Business (CD The Eminem Show, Juni 2002) [HipHop].

Mark Erelli: »The Only Way« (EP The Only Way, 2001) [Folk Rock].

Five For Fighting: "Superman (It's Not Easy)« (CD-Single, Sept. 2001) [Pop].

Radney Foster: »Everyday Angel« (CD Another Way To Go, Aug. 2002) [CountryPop].

Ricardo Franco: »Tribute To FDNY« (MP3, 23.9.2001) [Folk] [http://artists.mp3s. com/artists/497/ricardo_franco.html].

Kirk Franklin feat. Bishop T.D. Jakes: »911 (CD The Rebirth Of Kirk Franklin, Feb. 2002) [R\&B/Gospel]. 
Don Ricardo Garcia: »Rap Attack - Sept 11, 2001« (CD Out Of Egypt, 2002) [Christian Rap] [http://www.cdbaby.com/DRG3; http://donricardogarcia.com/ Page1.htm].

Pamela Goodberry: »We Will All Stand For Freedom« (Single-CD/MP3, komp. 12.9. 2001) [Pop] [http://www.wewillallstandforfreedom.com/download.htm].

Gorillaz \& D 12 feat. Terry Hall: »911« (MP3/Video, Nov. 2001) [HipHop] [http:// www.emimusic-spain.com/d12_gorillaz/music.html; http://www.emimusicspain.com/d12_gorillaz/video.html].

Tricia Greenwood \& James Robinson: »In Heaven 9-11« (MP3/Video, komp. 30.9.2001) [Pop] [http://www.upbeats.com/inheaven911].

Kim \& Reggie Harris: "Short Shift At Ground Zero" (CD Simplicity, 2002) [Gospel/Spoken Word] [http://www.kimandreggie.com/gnd_zero.htm].

John Hiatt: »New York Had Her Heart Broke« (MP3, live 27.11.2001) [Folk] [http:// www.hiatt.qtvr.com/New_York.htm].

Bob Holiday: »I Was There « (auch unter den Titeln »Silent Night 9-11«, »Met In The Stairwell « oder »The God Song « im Netz) (Single-CD/MP3, 2001) [Spoken Word with Accompaniment] [http://www.bpfrommer.com/September 11 Song 1 Was There.htm; http://www.countrygoldusa.com/god_was_everywhere.asp].

Whitney Houston: "Don't Cry For Me« (MP3, live 2001) [R\&B/Gospel] [http://www. geocities.com/americagodblessyou/dontcryforme.html].

Intrigued: »American Heroes (9-11-01)« (Single-CD/MP3, 2002) [Pop] [http://www. intriguedband.com].

Daniel J: »9-11/I'm All Right « (MP3, 2002) [Pop] [http://www.danieljmusic.com/ imalrightlyrics.htm; http://framisdave.com/911tribute.htm].

JACK of all Trades [Schweden]: »Heard It On The Radio (Sept. 11th Tribute) (MP3, 12.9.2001) [Rock] [http://www.mpulse.com/msong.asp?sID=7494; http://www. jackofalltrades.tk].

Alan Jackson: »Where Were You (When The World Stopped Turning)« (Live Sept. 2001; CD Drive, Jan. 2002) [Country-Pop].

Kristy Jackson: »Little Did She Know (She'd Kissed A Hero)« (Single-CD/MP3, 2001) [Pop] [http://www.littledidsheknow.com].

Bert Jansch: »Bright Sunny Morning “ (CD Edge Of A Dream, Okt. 2002) [British Folk] KRS-One: »Tears« (CD Spiritual Minded, Jan. 2002) [HipHop].

Jennifer LaMountain: »Together We Will Stand (MP3/Video, 2001) [Pop] [http:// www.morningsong.org/Artists/LaMountain/_videos/Together/Together.html].

Joaquim Lé: »Nine Eleven« (MP3, 2001) [Rock] [http://www.grafix.net/musica/ 911.htm].

Lil' Romeo: »We Can Make It Right « (CD Game Time, Dez. 2002) [HipHop].

Jim Lesses [Australien]: »Night Falls Over Manhattan « (CD Sometimes I Wake Up Naked, Juli 2002) [Folk] [http://www.jimlesses.com/manhattan.html].

Live: »Overcome« (Single-CD, 18.9.2001) [Pop].

Scott Loeb: "September 11th" (MP3, 2001) [Folk] [http://www.mp3.com/ scottloeb; http://www.geocities.com/sldice/sept11.html].

William McMillan [Kanada]: »Side By Side« (MP3, komp. 12.-14.9.2001) [Folk] [http://www.billmcmillan.com/Tribute].

Natasha Miller: »Eleventh Of September, 2001 (CD Her Life, 2002) [Folk] [http:// www.natashamiller.net/html/lyrics/7_11thsept.htm].

Masterminds: "September In New York« (CD Stone Soup, Feb. 2002) [HipHop].

Brett Michaels [von Poison]: »One More Day« (komp. Dez. 2001; CD Songs Of Life; Mai 2003) [Acoustic Pop].

Benjamin Milburn \& Nu'Dae: "You Can Be Free (A Song For America)« (Single-CD, 2002) [Christian Pop mit Doku]. 
Jon Nolan: »Eleven September (MP3, komp. 14.9.2001) [Folk] [http://eleven septembersong.com].

Danny O'Flaherty \& Khaetidawne Quirk: "Angel Fireman« (Single-CD; CD Heroes, 2002) [Celtic Folk] [http://www.celticnationsworld.com/mall/music-CDsDoflaherty.asp; http://www.cdbaby.com/cd/oflaherty3].

Elias Ortiz \& Danny Mellado: "September 11th, 2001 (MP3, 2002) [Pop mit Doku] [http://scootiemusic.tripod.com].

Tom Pacheco: "Heroes« (CD There Was A Time, Sept. 2002) [Folk] [http://www. talentconnections.com/artists.shtml].

Papa Roach: »Lovehatetragedy« (CD Lovehatetragedy, Juni 2002) [Rock].

Dolly Parton: »Hello God« (CD Halos \& Horns, Juli 2002) [Country].

Tom Paxton: "The Bravest (2001; CD Looking For The Moon, Okt. 2002) [Folk] [http://www.efolkmusic.com/viewartist.asp?artist=Tom+Paxton].

Al Petrone: »This New York« (CD Once Upon A Song, 2001) [Folk] [http://www. alpetrone.com].

Alan Pitts: "September 11, 2001 (A Tribute To The World Trade Center)« (MP3, 2001) [Pop] [http://www.mirc-colors.com/wtcsong.html].

Greg Poulos: "9-11« (MP3, 2001) [Folk] [http://groundzero.nyc.ny.us/memoirs/911-song].

Dolly Rappaport: »How Could This Happen? 9-11-01« (MP3, 2001) [Soft Rock] [http://www.besonic.com/BeSonic/User/0,4675,g0r0l0t0o1i423787,FF.html].

Suzzy \& Maggie Roche: "New York City « (CD Zero Church, Jan. 2002) [Folk] [http://www.roches.com/suzzy; http://www.redhouserecords.com/157.html].

Rush: »Peaceable Kingdom« (CD Vapor Trails, Mai 2002) [Rock].

Sackcloth2joy: "September Days« (CD Reflections, Juni 2002) [Christian Pop] [http://www.sackcloth2joy.com/reflections.htm].

Les Sampou: "September 11th: A Tribute (MP3, 2002; komp. in der Woche nach dem 11.9.2001) [Folk] [http://www.lessampou.com/song-september11.html].

Carlos Santana feat. Placido Domingo: »Novus (CD Shaman, Okt. 2002) [Pop].

Second Sight: »When Freedom Reigns« (Single-CD/MP3, 2002) [Pop] [http://www. secondsightband.com/main.htm].

Patti Shea: »All These Angels« (Single-CD/MP3, 2002) [Pop] [http://www.pattishea. com].

Ricky Skaggs \& Kentucky Thunder: "Weapon Of Prayer (In Honor And Memory Of September 11, 2001)《 (Single-CD/MP3, 2002) [Country] [http://www. skaggsfamilyrecords.com/weaponofprayer].

Michael W. Smith: »There She Stands (Single-CD; CD Worship Again, 2002) [Christian Pop] [http://www.reunionrecords.com/mws/see/thereshestands/ stands.htm].

Soulfly: "9-11-01 (CD Soulfly 3, Juni 2002) [One Minute of Silence].

Tracy Stephens: »9-11« (CD The Road I'm On, 2001) [Blues Rock] [http://www. tracystephens.net].

Wayne Tate: »Well Done« (MP3, Aug. 2002) [Christian Folk] [The story of Reverend Al Braca, who died while leading a group in prayer during the World Trade Center collapse; http://www.mymusicdog.com/artist/music_dog_artist.html].

Holt Vaughn: »Twin Towers (Song For America)« (MP3, 2001) [Folk Rock] [http:// www.songforamerica.com].

Minnie Villanueva \& Jose A. Maymon: »Forever To Remember (In Remembrance Of September 11, 2001)« (MP3, komp. 14.9.2001) [Pop] [http://www.freewebs. com/forever_to_remember].

Voices Of Hope [All-Star Assembly]: »In God We Trust« (CD Various Artists: Dove Hits 2002, Juni 2002) [Christian Rock]. 
Morris Walker: »The Twins: A Song For America« (MP3, komp. 13.9.2001) [Folk] [http://www.stevemartinmagicyears.com/Enduring_freedom/twins_words.htm]. Van Walworth: »The Army Of 9-1-1« (komp. 11.9.2001; CD United We Will Stand, Okt. 2001) [Country] [http://www.tapestryrecords.com/music.htm].

Rick Weaver: "Till The End (In Memory of those who lost their lives on September 11, 2001)« (MP3, 2001) [Folk] [http://ricktunes.com/Songs/Audio/till_the_end_ audio.htm].

Michelle Williams [von Destiny's Child]: »Better Place $(9.11)$ (CD Hearts To Yours, März 2002) [Gospel/R'n'B].

Andrew WK: »I Love NYC « (CD / Get Wet, Nov. 2001) [Rock].

Wu-Tang Clan: »Rules« / »Back In The Game« (CD Iron Flag, Dez. 2001) [HipHop].

Zay Zay: »America's Cry« (Single-CD/MP3, 2002) [HipHop] [http://www.cdbaby. com/cd/zayzay; http://www.zayzay.com/zzmusic.html].

D. Ziems: »The Ballad Of John O'Neill« (MP3, Sept. 2002) [Folk] [http://www. failureisimpossible.com/essays/oneill.htm].

\subsection{Longplay CDs mit 9/11-Bezug}

Laurie Anderson: Live At Town Hall New York City September 19-20, 2001 (DoppelCD, Sept. 2002) [Experimental].

Tracks: »Here With You«, "Statue Of Liberty«, "Let $X=X \ll$, »Sweaters«, »My Compensation «, »Washington Street«, "Pieces And Parts«, "Strange Angels«, »Dark Angel«, »Wildebeests«, »One Beautiful Evening«, »Poison«, »Broken«, »Progress «, Animals«, »Life On A String «, »Beginning French«, »0 Superman«, "Slip Away«, "White Lily«, "Puppet Motel«, "Love Among The Sailors«, »Coolsville«.

Steve Earle: Jerusalem (CD, Sept. 2002) [Country-Rock].

Tracks: »Ashes to Ashes«, »Amerika v. 6.0 (The Best We Can Do)«, »Conspiracy Theory«, »John Walker's Blues«, »The Kind«, »What's A Simple Man To Do?«, »The Truth «, "Go Amanda«, »l Remember You«, »Shadowland«, »Jerusalem«.

Pearl Jam: Riot Act (CD, Nov. 2002) [Grunge]..

Tracks: »Can't Keep«, »Save You«, »Love Boat Captain«, »Cropduster «, »Ghost«, "| Am Mine«, »Thumbing My Way«, »You Are«, »Get Right«, »Green Disease «, »Help Help«, »Bushleaguer «, »1/2 Full«, »Arc«, »All Or None«.

Sleater-Kinney: One Beat (CD, Aug. 2002) [Rock].

Tracks: »One Beat«, »Far Away«, »Oh!«, »The Remainder«, »Light-Rail Coyote«, »Step Aside«, »Combat Rock«, »Oxygen«, »Funeral Song«, »Prisstina«, »Hollywood Ending «, "Sympathy«.

Bruce Springsteen: The Rising (CD, Juli 2002) [Rock].

Tracks: »Lonesome Day«, »Into The Fire«, »Waitin' On A Sunny Day«, »Countin' On A Miracle «, »Nothing Man«, »Empty Sky«, »Worlds Apart«, »Let's Be Friends (Skin To Skin)«, »Further On Up The Road«, »The Fuse«, »Mary's Place«, »You're Missing «, »The Rising «, »Paradise «, "My City Of Ruins «.

Suicide: American Supreme (CD, Okt. 2002) [Electronic/Noise] [http://www. suicide.tv/av_content.html].

Tracks: »Televised Executions«, »Misery Train«, »Swearin' To The Flag«, »Beggin' For Miracles«, »American Mean«, »Wrong Decisions«, »Death Machine «, »Power Au Go-Go«, »Dachau, Disney, Disco«, »Child, It's A New World«, »I Don't Know«.

Various Artists: 911 AMERIKA (CD, Mai 2002) [HipHop].

Tracks: Zachary Self: »Front \& Center «, Wise Proof, Annie J., Gabriel, Castro: »Bloody Rain«, Ace, Redeye, WD4D, Scene, E-Rok: »The Conference«, Yirim Seck, Monk-Wordsmith, Tom Gray: "Situations Critical«, Michelle Mukai: 
"Strange Days«, "September 11th, 2001 (Interlude)« ft. the voices of Medusa, Cornel West \& Malcolm X, Rajnii, Zachary, Gabriel: »Assist Us«, Vitamin D, Silas Blak, H-Bomb: »The Aftermath«, El Saba: "God Bless Humanity«, Khalil Crisis: "Centurion«, »Interlude«, E-Real Asim \& Surge Spitable: »Karma«, Influenz: »Blind (Head Of The Snake)«, Castro, Silas Blak, Kylea, Specs, Wise Proof: »A Call To Arms «, One Family: »Beginnings, Isiah 2:4«.

Various Artists: Love Songs For New York, Wish You Were Here (CD, April 2002) [http://www.villagevoice.com/lovesongs].

Tracks: Moby: »Memory Gospel«, Cornershop: »Returning From The Wreckage«, Mekons: »I Love The Big Apple«, Joseph Arthur: »Build Back Up«, Moe Tucker: »Fired Up«, Andrew WK: »I Love NYC «, Hydraulic Funk with Afrikaa Bambaataa: "Lay Down Candles In The Rain«, Ari Upp: »Don't Say Nothing Bad About NY«, Sheila Chandra: »11«, Hakim: »Hava Habiby«, Gogol Bordello: »Baro Faro«, Uri Caine: »New York, New York«, Loudon Wainwright III: »No Sure Way«, The DuTels: »We're Still Here«, Atmosphere: »Summer Song«, Baaba Maal: »Djirabi«, Matthew Shipp: »Amazing Grace«, Lenny Dee: »Xtreme Terror«.

\subsection{Tribute Songs}

All Star Tribute: »What's Going On?« (Single-CD, Okt. 2001) [Pop] (Benefiting the survivors of September 11; CD mit Christina Aguilera, Backstreet Boys, Mary J. Blige, Bono, Destiny's Child, P Diddy, Jermaine Dupri, Fred Durst, Eve, Nona Gaye, Darren Hayes, J-Lo, Alicia Keys, Aaron Lewis, Nas, Nelly, N'Sync, Britney Spears, Gwen Stefani, Michael Stipe u.a.).

AMJaz: "Aftermath WTC « (MP3, 2002) (Benefiting the American Red Cross relief effort for NYC and DC) [Blues] [http://www.artvilla.com/aaapoetry; http:// www.besonic.com/User/0,1391,g0r0l1t0o0i413258,FF.html].

ArlaVeer: »WTC 911« (Single-CD, 2001) [Electronica mit Doku] (Benefiting the American Red Cross) [http://stations.mp3s.com/stations/233/september_11_ tribute.html].

Lucie Arnaz: »Heaven Knows« (Single-CD, 2001) [Pop] (Benefiting the World Trade Centre Twin Towers Fund) [http://www.luciearnaz.com/lyrics.html].

Bob Barbuto: "Standing Tall« (Single-CD/MP3, 2001) [Pop] (Benefiting the UFAWCF - United Firemens Association Widows and Children Fund) [http://dynrec. $\mathrm{com} / \mathrm{wtc}]$.

Laura Baron: »We Will Stand Together (Single-CD, 2001) [Folk] (Benefiting a charitable relief fund) [wewillstandtogether.com].

Chris Barron [von Spin Doctors]: "We're All New Yorkers Now« (Single-CD, 2001) [Rock] (Benefiting the Twin Towers Fund) [http://www.cdbaby.com/cd/ chrisbarron2].

Diana Belkowski \& Dan Tramon: "We Rise From Ashes« (Single-CD, 2002) [Pop] (Benefiting The Twin Towers Fund) [http://www.cdbaby.com/cd/dianandan; http://www. werisefromashes.com].

Carvelli: »New York Angels« (Single-CD, 2001) [Rap with R\&B] (Benefiting the Red Cross Fund for the victims and their families affected by the New York attack on September 11, 2001) [http://www.carvelli.com/index2.html].

Catholic Artists for Relief: "You Are Not Alone« (CD-Single/Video, aufg. Okt. 2001) [Pop] (Benefiting The Armed Services YMCA Pentagon Survivors Fund) ['Song of the Year', 'Group of the Year ' und weitere 8 der Catholic UNITY Awards 2002; http://www.catholicmusicnetwork.com/profiles/CatholicArtistsForRelief.htm].

Mark Cicero: „Our Heroes Are Crying “ (MP3, 2002) [Folk] (Benefiting the UFA Widows and Children's Fund) [http://www.tweetsnest.com/heroescrying.html]. 
David Clayton-Thomas: »The Lights Of Broadway (EP, 2002) [Rock] (Benefiting the September 11 Widows and Victims Families Association) [http://www. davidclaytonthomas.com].

Daryl Jr. Cline \& Friends: "Give Them Wings« (Single-CD, 2001) [Rock] (Benefiting Funds for victims of Sept. 11th) [http://www.jrcline.com/Benefit.html].

Judy Collins: »Kingdom Come - The Fireman's Song “ (MP3-Purchase, 2001) [Folk] (Benefiting the Uniformed Fire Fighters Scholarship Association Fund) [http:// www.judycollins.com/9-11-mp3Download.html].

Jessie Allen Cooper: 9-11-2001 (CD, 2002) [Electronica mit Doku] (Benefiting the Jessie Allen Cooper Children's Fund, which will help to bring the arts back to public schools) [http://www.nowgetcreative.com/911cd.htm].

Tracks: »Mayor Of New York«, »Out Of The Shadows «, »Re-Mix / President Of USA «, Lament «, »Flight 11«, »Aspects Of The Heart«, »Dark Tuesday«, »Wednesday's Reflection«, »The End Of Innocence«, »A Meditation«, »Mystery Of Iniquity, »Prayer For Peace «.

Sharon Costello: »Follow In Your Footsteps « (Single-CD, 2002) [Pop] (Benefiting the International Firefighters Fund of America) [http://www.cdbaby.com/cd/ sharon2].

Jim Coyne: »A Sacrifice So Dear (The Firefighter Song)« (Single-CD/MP3) [Irish Folk] (Benefiting NYC Fire Dept. widows and children) [http://www.geocities.com/ firefightersong].

Jim DiSpirito \& Carol Lee Espy: "Circle Of Love« (Single-CD, 2001) [Rock] (Benefiting Denis Leary's 'Fireman's Fund for New York's Bravest<) [http://www. cdbaby.com/cd/dispirito].

Kitty Donohoe: "There Are No Words « (Single-CD/MP3, aufgen. 20.9.2001) [FolkPop] (Benefiting the Relief Efforts in New York City) [http://www.kittydonohoe. com].

Allison Downey: "On The Day (September 11, 2001) (MP3, 2001; CD Wind At Your Back) [Folk] (Benefiting The September 11th Fund) [http://www.allisondowney. com].

For Kids Only: »Light A Candle For The Child « (Single-CD, 2001) [A-Cappella-Pop] (Benefiting the children of the victims of Sept. 11th resp. the For Kids Only Medical and Scholarship Fund) [http://for-kids-only.org/candle.htm].

Foundry \& 60 Firefighters and Police: »For The Rest Of My Life (Single-CD/MP3, 2001) [Pop] (Benefiting the Twin Towers Fund) [http://www.september11tribute.org/Music/ForTheRestOfMyLife.htm].

Gashouse feat. Tony Priscaro: »God Bless The USA 2001« (Single-CD/MP3, 2001) [Pop] (Benefiting the Salvation Army's Disaster Relief Fund) [http://www. ligonier.com/gashouseannie/usa.html].

Lauren Gibbs: "American Pride (Single-CD/MP3, 2001) [Pop] (Benefiting Families of Freedom, helping the children and spouses of the victims of the September 11, 2001 >Attack on America realize their educational dreams) [http://www. standtogether.net].

Gotham Artists: "911 (Single-CD/MP3, Okt. 2001) [Pop] (Benefiting the American Red Cross) [http://artists.mp3s.com/artists/315/gotham_artists.html].

Tara Greico: "Patriots Day Anthem (CD-Single, 2002) [Hymn] (Benefiting the widows and orphans of the Police, Firemen, and EMS Workers who died in the line of duty due to the terrorist attacks on September 11th) [http://www. patriotsdayanthem.com; http://www.cdbaby.com/cd/taragreico].

Gary Harvey: »911 (Single-CD/MP3, aufgen. 12.9.2001) [Folk Rock] (Benefiting the NY Firefighters Fund) [http://www.celebritydirect.org/harvey/911.htm]. 
Topp Hennessee: »September Sky« (Single-CD, 2001) [Folk] (Benefiting the Families of Freedom Scholarship Fund, set up to help the children and spouses of the victim's of the September 11, 2001 attacks) [http://www.topphennessee. com/html/index.html].

Michael Jackson \& Friends: "What More Can I Give« (Live-Video, Benefizkonzert United We Stand am 21.10.2001 im RFK Stadium, Washington D.C.) [Pop].

Mo Jingles: »Message From Above $(M P 3,2001)$ [Pop] (Benefiting the American Red Cross Disaster Relief Fund) [http://www.mojingles.com/911tribute.htm].

Kenny G: »Auld Lang Syne (Freedom Mix) (Maxi-Single, Nov. 2002) [Saxophon mit Doku] (Benefiting the NY Fire Fighters).

Phillip Kohberger: »Rainbow On Blue (Single-CD, 2002) [Pop] (Benefiting the Tribute in Light and the 9/11WTC Relief Fund) [http://www.cdbaby.com/cd/ phillipk].

Surrey Lane: »Love Must Grow« (Single-CD/MP3, 2001; komp. 11.9.2001) [Folk] (Benefiting the Chris Dunne Foundation) [http://www.cdbaby.com/cd/surreylane].

Richard Lawton and Track 9 Band: »Nine Eleven (Tribute To Heroes)« (MP3, 2001) [Rock] (Benefiting the 9-11 Relief Fund) [http://www.lawtonstudios.com/NINE_ ELEVEN.html].

Paul McCartney: »Freedom« (Single-CD, 5.11.2001) [Pop].

Kelvin McGee: "We'll Raise Our Flag « (Single-CD, 2001) [Pop mit Doku] (Benefiting the Red Cross Fund) [http://www.cdbaby.com/cd/mcgee].

Bette Midler: »Wind Beneath My Wings « (MP3, 2001) [Pop] (Tribute to the men and women of the New York City Fire Department, produced by Tim Pilcher of Premiere Radio Networks) [http://www.z995.com/america/default.asp].

Mr. Food: "Freedom Is Calling " (Single-CD/MP3, 2001) [Pop] (Benefiting the American Red Cross Disaster Relief Fund) [http://www.athomewithmrfood.com/ freediscaltr.html].

Gordon Munding: »A Song To New York« (Single-CD/MP3, 2001) [Rock] (Benefiting the World Trade Center Relief Fund) [http://www.dynrec.com/dhblues.html].

Rick Mundy: »Time Stood Still« / »Freedom Rings « (Single-CD, 2001) [Country] (Benefiting the Firefighters National Trust) [http://timestoodstill.org].

John Murphy: »Merry Christmas Angel« (Single-CD, rel. 20.12.2001) [Pop] (Benefiting the World Trade Center Relief Found) [http://www.taylormademusic.net/ html/merry_christmas_angel.html].

Mark Nelson: »Knocking On Heaven's Door « (Single-CD, 2001) [Pop] (Benefiting the New York Fire Fighters 9-11 Disaster Relief Fund) [http://www.cdbaby.com/ $\mathrm{cd} /$ iaffhelp].

New York State Court Officers: God Bless America - United We Stand - 9-11-01 (CD, 2002) [Pop] (Benefiting the Court Families Assistance Fund) [http://www. cdbaby. com/cd/uws].

Tracks: »Raise A Flag«, Goodbye«, »Stand Strong«, »United We Stand«, »One September Day«.

Merrill Osmond: »America« (Single-CD/Live-Video, Dez. 2001) [Rock] (Benefiting the Families of Freedom Scholarship Fund) [http://www.merrillosmond.com/ america.html].

Dani Owens \& Amy Sheehy: "My Country « (Single-CD, Okt. 2001) [Kinderchor] (Benefiting the American Red Cross Relief Effort for victims of the attacks) [http://www.kidsofamerica.org/\#].

Tod Pierce: "Ground Zero« (Single-CD, 2002) [Rock] (Benefiting the Twin Towers Orphans Fund) [http://www.cdbaby.com/cd/todpierce]. 
JC Tubbs \& The PSA [Portland Songwriter's Association] Chorus: "Yes We Can! « (Single-CD/MP3, 2002) [Folk] (Benefiting the WPI Fireman's Fund) [http://www. cdbaby.com/cd/jctubbs2; http://artists.iuma.com/IUMA/Bands/JC_Tubbs,_ The_Tumbleweed_Troubadour/index-1.html].

The Chamber-Made Brigade: "The Fireman Song (The Ballad of Mike Moran)《 (Single-CD/MP3, 2002) [Irish Folk] (Benefiting New York Relief efforts, and Fire \& Rescue/survivors funds) [http://www.firemansong.com].

Benjamin Wagner: »Crash Site « (Single-CD, Sept. 2001) [Folk Rock] (Benefiting the United Way's September 11th Fund) [http://www.benjaminwagner.com; http:// www.cdbaby.com/cd/benjaminwagnersgl].

\subsection{Tribute Compilations}

Artists World Trade Center Relief Fund: We Will Never Forget (MP3-CD, 2001) [http://stations.mp3s.com/stations/233/artists_world_trade_center_rel.html].

Dokus/Tracks: >World Trade Center Eyewitness Report 1<, Nick Jason: »The City (World Trade Center Tribute)«, >World Trade Center Eyewitness Report 2‘, Ganimead: »09-11-2001 «, >Archbishop of Canterbury Homily 9-14-01<, Deliciound: »In Memorium, September 11th 2001«, Forrest Lee Jr.: »God Bless America (9-112001 Tragedy)«, AutoCad: »Let's Try Again«, ,President Bush - National Memorial Service`, Alba Zone: »Miss You«, `One Congressperson Votes for Peace<, Robert Thomson: "September 11, 2001«, Project 12:01: "September 11th Lament«, 'The Lord's Prayer - UK Memorial Service .

United Synthpop Artists: A Tribute To America (CD, 2001) (Benefiting the September 11th Fund of the United Way) [http://www.twothousandbc.com/ tribute.html].

Tracks: Project 12:01: "September 11th Lament«, Ganymede: "After The Fall (New York Mix)«, Monolithic: »Goodbye (For Now)«, NukleoN: »Infidel «, Madmen in Vienna: "These Strange Times«, Empire State Human: "Stare (Skintone Mix) Wave in Head: "Criminal Ballad«, Blind Before Dawn: »United For A Day (Eloquent Mix)«, Etherstrings: »Heavens Cry«, Cosmicity: »The Perfect Shape«, The Silent Wave: "Far Away«, Selected Area: "Anywhere (2001 Mix)«, OCCUPANT: "Stand Strong (Synomatic Mix)«, Tony Reed: »America At War; Gary Flanagan: »Hope Will Survive«, Piper: »Proclamation (Funk-it-up Bush Mix)«, Loveless: »Wishing 2001《.

Various Artists: America: A Tribute To Heroes (Live-Doppel-CD, 4.12.2001) (Benefizkonzert am 21.9.2001 parallel in New York und Los Angeles, von über 8000 Fernseh- und Radiostationen live übertragen. Benefiting the United Way's September 11th Telethon Fund).

Tracks: Bruce Springsteen: »My City Of Ruins«, Stevie Wonder feat. Take 6: "Love's In Need Of Love Today«, U2: "Walk On«, Faith Hill: »There Will Come A Day«, Tom Petty \& The Heartbreakers: »I Won't Back Down«, Enrique Iglesias: "Hero«, Neil Young: »Imagine«, Alicia Keys: »Someday We'll All Be Free«, Limp Bizkit with John Rzeznick [von Goo Goo Dolls]: »Wish You Were Here «, Billy Joel: "New York State Of Mind«, Dixie Chicks: "| Believe In Love«, Dave Matthews: Everyday«, Wyclef Jean: »Redemption Song «, Mariah Carey: »Hero«, Bon Jovi: "Livin' On A Prayer «, Sheryl Crow: "Safe And Sound«, Sting: »Fragile«, Eddie Vedder: »Long Road«, Paul Simon: »Bridge Over Troubled Water«, Celine Dion: »God Bless America«, Willie Nelson: »America The Beautiful«.

Various Artists: Bands For America (CD, 13.11.2001) (Benefiting the September 11th Fund of the United Way) [http://www.freshtracksmusic.com/CDoM/bfa. asp?typeid=5\&monthid=0].

Tracks: Jack Johnson: »Mud Football«, The String Cheese Incident: »Outside and 
Inside «, O.A.R.: »Hold On True«, Dispatch: »Passerby«, Sonia Dada: »Ain't Life For The Living «, Cary Pierce \& Friends: »I Believe In America«, Graham Colton: "Save Me«, Virginia Coalition: "Luminiferous Ether «, Domestic Problems: "James Francis«, Strangefolk: »Go To A Show«, King Konga: "Something Good«, Lucky Town: »Dirty Shoes «, Pepper's Ghost: »Sad, Sad Song «, Smartbomb: »Movie Of The Week«, The Booda Velvets: "Staring At The Sun«, Slightly Stoopid: »Wiseman«, Garrett Dutton [von G Love \& Special Sauce]: »On 9.11.01«.

Various Artists: Jersey's Talkin (Live-CD, aufgen. Nov. 2001) (Benefiting The NY Fire Fighters 9-11 Disaster Relief Fund) [http://www.cdbaby.com/cd/blueskid].

Tracks: TVO Band: "Moondance«, Pozzatorti: "Let Me Love You«, B.B. \& The Stingers: »Haunted House «, The Alice Project: »A Room of Our Own«, Yasgurs Farm: »Open Invitation«, Billy Hector: »Beast of Burden«, The Joe Morrison Experience: "Superstition«, Hot Sauce: "Love Struck«, Mango Brothers: »Jersey Girl«, Floyd Phillips \& The Mudflaps: »Mojo«, Bernie Worrell \& The Woo Warriors: "Biological Speculation«, OA's Sunday Night House Jam Band: »Matchbox«, The Alice Project: »Goodbye Old Friend«.

Various Artists: Let Freedom Sing: A Kansas City Tribute to the Heroes of September 11, 2001 (CD, Nov. 2001) (Benefiting Heart to Heart International) [http://www.hearttoheart.org/news/CDPressRelease.html].

Tracks: Connie Dover: "Amazing Grace«, Ida McBeth \& The 24-member KC Chorale Choir: »Battle Hymn Of The Republic «, Angela Hagenbach: »America«, The Shenanigans: »Danny Boy«, Kimberly Lord: »Inch By Inch; Bukeka Shoals: »'ll Light A Candle In Your Name«, Independence Messiah Choir: »Star Spangled Banner «, KC Chorale: "Sing Me To Heaven«, Danny Cox \& Children of New Chelsea Elementary in Kansas City: "The Beauty Of Diversity«, Danny Cox: »Angels Of The Nighttime, Angels Of The Day«, Buck O'Neil: »| Believe«, All Artists: "America The Beautiful«.

Various Artists: Let's Roll: Together in Unity, Faith and Hope (CD, Sept. 2002) (Benefiting the Todd $M$. Beamer Foundation, which helps children affected by September 11th) [http://www.letsrollmusic.com/index.html].

Tracks: dcTalk: »Let's Roll«, 38th Parallel: »Horizon«, James Curlin: »| Believe«, Lila McCann: »Who Else Could It Be?«, Jennifer Knapp: »Light Of The World«, Nick Moroch \& Don Potter: »Interlude«, Wynonna: »Carry On«, Nicole C. Mullen: "I See You In His Eyes«, Shane Minor: »Don't Ask Why«, Joy Williams, Jody McBrayer \& James Curlin: "With New Eyes«, Selah, James Curlin, \& Jody McBrayer: "We'll Praise Your Name«, Chaka Khan: »Lullaby«, Pam Kenyon Snider: "How Great Thou Art«, LA Session Choir: »Our Father«, Phil Keaggy: Daily Bread«, James Curlin: The Lord's Prayer «, Anointed (an all-star collective): "To You Be The Glory«, Yo Yo Ma: »In His Arms«.

Various Artists [Japan]: Nine Eleven Two Thousand One (CD, Jan. 2002) (Benefiting the 9.11 Fund) [Hardcore/Metal] [http://www.kentaxrecords.com/news.htm].

Tracks: Hoods: »Days In Heads«, Vietnom: »Fall Out«, Cold Front: »You're The One«, Everybody Gets Hurt: »Home Front«, Through The Discipline: »Requiem Mass«, Eye 2 Eye: »Rise To Fall«, 36 Deadly Fists: »Locked Away«, Sworn Enemy: »Pain«, Vic20: »Tainted Loins«, Mack Demon: »Can't Stop Won't Stop«, Full Blown Chaos: »It Remains«, Awkward Thought: »Pulled By A Chain«, Strength For A Reason: »Not Forgotten«, Boxcutter: »Worldwide«, 5 Minute Major: "Trust«, One 4 One: »Tomorrows Dawn«, No Redeeming Social Value: »Old-E Fever «, Eyes Of Hate: »Contradiction«, Train Of Though: »Bliss«, Denied: »Dear Friend«, Wisdom In Chains: »B.F.L. Anthem«, On The Rise: »On The Rise «, Irate: »Always Remains«.

Various Artists: One City. A Tribute to $9 / 11$ by over 75 Boston Area Musicians (CD, 2002) (Benefit compilation by BACBEAT: Benevolent American Coalition Boston Entertainers Against Terrorism, proceeds go to the American Red Cross 
Disaster Relief Fund) [http://www.bacbeat.org/onecity.htm].

Tracks: Boston Police Gaelic Column of Pipes and Drums: »Amazing Grace«, Tony Island etc.: "OneCity«, The White Heat Swing Orchestra: "Sing, Sing, Sing ", Suzanne Clark etc.: »Courage My Soul (Faith In Action)«, Sal Difusco: »Live Free Or Die «, Denis Montgomery and the Denis Montgomery Choir: "My Country Tis of Thee«, Joe Galeota etc. : "Drums Of A Nation«, Shirley Lewis etc.: »America the Beautiful«, Kevin Harris etc.: »God Bless America«, Little Joe Cook etc: »In God We Trust«, Sgt. Daniel M. Clark, Richard Giglio: »The National Anthem«.

Various Artists: Operation Ground Hero. A Tribute To The Heroes Of NYC (CD, Juni 2002) (Benefit compilation by The Asian American community, proceeds go to the September 11th Fund and its efforts to assist the families directly affected by the WTC attacks) [http://www.kamikazerecords.com/groundhero/artists. html].

Tracks: Forté: »Remember The Heroes (Dedicated to the Heroes of 9-11)«, Billy Crawford: »| Wish«, Jocelyn Enriquez: »Faith, Hope and Prayer «, Disguyz: »Our Nation In Song «, Noly: »| Love«, Magno: »Fall«, Touch: »| Want To Live On«, rb: "Dream Come True (My Hero)«, 6th Day: »Your Call«, April: »Stay Real«, One Vo1ce: »I Don't Wanna Dance Alone «, LOURDS: »America United «, Rogeniv [von UZ4]: »Their Music Will Last Forever«, Devotion: "So Wonderful«, Funky Little Island People: »If I Can Say«, Touch: "Star-Spangled Banner«.

Various Artists: September Rising (CD, Okt. 2001) (Benefiting the New York Firefighters September 11 Fund) [http://www.septemberrising.com].

Tracks: Roger Dillon: "A Manhattan Day«, The Doc Side: »The Eroded Man «, Hiroaki Honshuku: "The View«, Babz: "Your Love's The Reason«, Melissa Axel: "The Worth Of Things «, Edison Suit: »Metaphysical Vertigo«, Oxygenhose: "Flight 93 (Don't Tread On Me)«, Christina Sanders: "New Day«, David Akina: "Climb«, Jerry Summers: »Tocado«, Dennis Kambury: »Requiem IXX|«, Steve Ball: »Elegy In 9/11«, Willy Dalton: »WTC911«, Sweet Crystal: »Lerue Deciel«, The Medicine Show: »I Heard The Bells Ring Today«, Dave Hearn: »Manhattan Elegy«, Zenta Sato: »Voices In The Air«, Trond Bjornard: "Angels Wings«, Christopher Neal: »We Will Unite .

Various Artists: Sound Relief Volume One: From CA To NYC (CD, Nov. 2001) (Benefiting the United Way's September 11th Fund) [http://www.cdbaby.com/cd/ soundrelief].

Tracks: Jay Buchanan: »Reborn«, Wonderlove: »Fork In The Road«, The Act Of Breathing In: »Invincible«, Sense Field: »First Things First«, Square: »Better «, Astoria: "Electricity«, Cheswick: "First Things Last«, The Killingtons: »Tie Me Under «, Campground Effect: »Behavioral Modification Program«, Limbeck: »Why Don't You Just Leave Already?«, Rachael Cantu: »Best Wishes«, Ryan Ferguson [von No Knife]: »Parachute«, Onelinedrawing: »With God On Our Side«.

Various Artists: Tears Of A Thousand Years (CD, 19.11.2001) (Benefit compilation by the Canadian Musicians September 11th Relief Foundation, proceeds go to the the New York State and Salvation Army September 11th Relief Funds) [http://www.tearsofathousandyears.com/home.html].

Tracks: Valdy: "When Peace Came To The Valley«, Lynn Harrison: "Laugh Myself To Sleep«, Brent Titcomb: »I Still Wish The Very Best For You«, Scott Cameron Smith: "If It's A Long Way Home«, David Bradstreet: »Tears Of A Thousand Years ", Katherine Wheatley: »My Last Breath «, Stan Rogers: »Jamie «, James Gordon: »Bomb Them With Butter«, Randy Uberig: »Once It's Gone«, The Laws: »Willow And The Dove«, Don Bray: »Burning In The Streets«, Doug McArthur: "Justice«, Eileen McGann: »Wisdom Guide Me«, Aengus Finnan: "Lately«, Fireweed: "Heaven's Restaurant«, Tim Harrison: »Prayer Watching«, Paul Langille: »There Is A Time«, D'Arcy Wickham: »In The Blink Of An Eye«, John Gracie: »Pass It On«, Susan Crowe: »When The Day Is Over«. 
Various Artists: The Canvas Remembers September 11 (CD, Sept. 2002) [Folk/Pop] (Benefit compilation by California Songwriters, proceeds go to inner-city children and the arts in New York City: Free Arts For Abused Children, NYC and Midori \& Friends) [http://discmakers.com/september11; http://www.cdbaby. com/cd/september11].

Tracks: Natasha Miller: »Eleventh Of September, 2001«, Austin Willacy: »Red White And Blue«, Wendy Beckerman: "You Never Know«, Brad Wilcox: »World Trembles «, Stacy Kray: »They Traded The World «, Neil Rutman: »I Was Born An Hour Ago", Linda Hirschhorn: »Born 9/11/85", Ken Kingsbury and Eric Weiss: "Where Eagles Dare«, Think of England: "Alive«, Paul Manousos: »World Interrupted«, John O'Brien: September 13«, Lynn Bobby: »Dark Days«, Glass House: »Build A Bridge«, KC Bowman: »The Super Bad Report«.

Various Artists: The Concert For New York City (Live-Doppel-CD, 27.11.2001) (Benefizkonzert am 20.10.01 im Madison Square Garden, NYC; initiiert von Paul McCartney. Benefiting the NYPD, FDNY and rescue workers).

Tracks: David Bowie: "America« / »Heroes«, Bon Jovi: "Livin' on a Prayer « / »Wanted Dead Or Alive« / »It's My Life«, Jay-Z: »Izzo (H.O.V.A.)«, Goo Goo Dolls: »American Girl«, Billy Joel: »Miami 2017« / »New York State Of Mind«, Destiny's Child: »Emotion« / »Gospel Medley«, Eric Clapton (feat. Buddy Guy): »I'm Your Hoochie Coochie Man«, Adam Sandler: »Operaman«, Backstreet Boys: "Quit Playing Games With My Heart«, Mick Jagger \& Keith Richards: "Salt Of The Earth / "Miss You«, Mike Moran: "FDNY«, The Who: "Who Are You« / "Baba O'Riley « / »Won't Get Fooled Again«, Melissa Etheridge: »Come To My Window« / »Born To Run«, James Taylor: »Fire And Rain« / »Up On The Roof«, John Mellencamp: "Peaceful World«, Pink (feat. Kid Rock): »Houses«, Five For Fighting: "Superman (It's Not Easy)«, Elton John: »Mona Lisas And Mad Hatters«, Paul McCartney: »I'm Down« / »Yesterday« / »Let It Be« / »Freedom (Reprise)«.

Various Artists: The Day America Cried - Songs Of Hope For A Unified Nation (CD, 23.10.2001) [Rock] (Benefiting the American Red Cross, United Way's September 11th Fund and other related charities) [http://www.tmgmusic.com/ tmgindex.htm].

Tracks: Johnny VanZant \& Jim Peterik: »The Day America Cried«, Brian Anderson: "Heroes Come \& Gone«, Jim Peterik \& World Stage feat. Johnny VanZant: »Can't Say It Loud Enough «, Kevin Chalfant \& Jim Peterik: »The Sum Of Our Hearts «, Johnny VanZant: "Alive«, Jim Peterik: »The Box«, Jim Peterik \& World Stage feat. Don Barnes: »Changed By Love«, The Storm: »Waiting For The World To Change«, Jim Peterik \& World Stage feat. Kelly Keagy: »Long Road Home«, Ides Of March: »The National Anthem«.

Various Artists: The World Will Remember - September 11th 2001 (CD, Okt. 2001) (Benefiting the Disaster Relief Efforts) [http://www.serge.org/disasterreliefCD; http://www.cdbaby.com/cd/worldremembers].

Tracks: Anne McCue: "Laughing «, Patti Witten: »Call The Angels«, The Alice Project: »Goodbye Old Friend«, Keri Rose: »Wild Butterfly«, Lady Jane Grey: "Twilight«, Dave Issacs: »Here On This Shore«, Laura Diamond: "Some Days I Don't«, Jody Whitesides: »Never Say Goodbye«, Lynda Johnson: »|'ll Find You«, Derrik Jordan: "Something Beautiful«, Dorothy Wallace: »There But For The Grace Of God«, Tasm Lab: »Demystified Disenchanted«, Neglected Sheep: »Time«, Gravity Crush: »To Remember You«, Jeannie Drago: »I'm Still In Love With You«, Janie Short: »Abide«, Pendulabellum: »Hymn«.

Various Artists: United We Stand (CD, 6.11.2001) (Benefiting the American Red Cross).

Tracks: John Lennon: »Imagine«, Lee Greenwood: »God Bless The U.S.A«, The Beach Boys: »4th Of July«, Brotherhood Of Man: »United We Stand«, The Persuasions: "Lean On«, George Throgood: »Let's Work Together «, Joe Cocker: 
»With A Little Help From My Friends«, Chris LeDoux: »| Believe In America«, Robbin Thompson: »Wouldn't Wanna Be You«, Woody Guthrie: »This Land Is Your Land ", Glen Campbell: »God Must Have Blessed America«, The O'Jays: »l Love America«, Al Green: »Amazing Grace«, George Adams: "Star Spangled Banner «.

Various Artists: vigil - n.y. songs since 9/11 (CD, April 2002) [Folk] (Benefit compilation by Suzanne Vega \& The Greenwich Village Songwriter's Exchange, proceeds go to the Jeff Hardy Memorial Fund) [http: //www.vigilcd.org].

Tracks: Christine Lavin: »Firehouse «, Jack Hardy: »Ground Zero«, Suzanne Vega: »It Hit Home«, Jon Albrink: »The Beauty Of The Day«, Wendy Beckerman: »You Never Know«, Bob Hillman: »World Trade Center «, Tim Robinson: »Louisa, From Her Window«, Richard Julian: »No Song«, Dawm Landes: »A Well Dressed Man«, Jack Hardy: »On A Clear Day«, Tim Robinson: »For Your Heart«, Ina-May Wool: "Box Cotters And Knives", Bob Hillman: "Communists", Brian Rose: "The Skyline«, Jill Gerwitz: »Been Around«, Andy Germak: »Spoonfed«, Wendy Beckerman: "Life Goes On«, Noam Weinstein: »Today«, Amy Marie Keller: »Never Forget «, Frank Tedesso: »When Mohammed Came To The Mountain«.

Various Artists: We'll Carry On (CD, Mai 2002) [Folk] (Benefit compilation by FDNY, PAPD, WTC volunteers and local NYC musicians, proceeds go to 911WVFA, PAPD WTC Disaster Survivors Fund, WTC Ground Zero Relief) [http:// weststreetrecords.com; http://www.cdbaby.com/cd/wellcarryon].

Tracks: Hughie Lynch (FDNY Squad 1): "Tomorrow«, Marc Blatte \& David Patillo: »Hole In The Sky«, Eric Milano \& Chris Pickford (FDNY): »Weight Of The World«, Norma Hardy (PAPD) \& Valerie Ghent (WTC GZ Relief): »The Men«, Greg Parr (FDNY Engine 58): »There Is A Light«, Ann Klein: »Waiting For The Snow«, Leni Stern: »Where Is God«, Kathleen Pemble (FDNY Engine 73 spouse): »Engine 73«, Tom Ferranola (FDNY Engine 167): "Sacrifice «, Stanley Brown: »Whatcha Gonna Do?«, Elisa Peimer: »Hope«, Chris O'Brien (son of retired Firefighter Chris O'Brien Sr.): »Fly Our Flag High«, Elizabeth Jordan: "Sanctified«, Larry May: All American«, Rosalinde Block (Volunteer for FDNY): »The Word Is Love«, Valerie Ghent (WTC GZ Relief): »We'll Carry On«.

\subsection{Patriotic Songs}

Blackhaw: "Days Of America" (CD Spirit Dancer, Jan. 2002) [Country].

The Bob Mullins Band feat. Greg Vail: »America The Beautiful / »Daybreak (In Remembrance)«(CD We Remember 9.11 - America The Beautiful, August 2002) [Jazz] [http://planetmullins.com/america.htm].

Brooks \& Dunn: "Only In America« (CD Steers and Stripes, April 2001) [Country].

Tom Callinan \& Phil Rosenthal: »These Colors Don't Run« / »America« (Single-CD 2 Songs For America) [Folk] [http://www.crackerbarrel-ents.com/tom_flag_lyrics. htm].

Radney Foster: »Everyday Angel« (2001, CD Another Way To Go, Aug. 2002) [Country-Pop].

Billy Gilman: »There's A Hero« (CD One Voice, Juni 2000) [Country].

Waylon Jennings: "The Eagle« (CD The Eagle, 1990) [Country].

Cledus T. Judd: »Don't Mess With America« (CD Cledus Envy, April 2002) [Country; a chest-poking parody of Brooks \& Dunn's »Only In America«] [http://www. williams-bell.com/cledus/bio.html].

Kathy Mattea: "Guns Of Love« (CD Roses, Juli 2002) [Country].

Mark McGuinn: »More Beautiful Today « (Single-CD, Juli 2002) [Country-Pop] [http://vfrrecords.com/markmcguinn/index.htm]. 
Mark Michael: »America Will Rise (Single-CD, 2001) [Country] [http://www. cdbaby.com/cd/markmichael].

Jody Miller: "Liberty Man« [Country] [http://www.macromusic.com/JodyMiller/ liberty_man.html].

Craig Morgan: »God, Family And Country« (Single-CD, Dez. 2001) [Country-Pop].

Ike \& Susan Mumpower: "America's Heroes« / "America's Tragedy« (MP3, 2001) [Country] [http://www.tributesongs.com].

Jennifer Renee: »Light A Candle In September! (The Patriot Day Song)« (MP3, 2001) [Pop] [http://66.223.12.161/september11Victims/LIGHT_A_CANDLE.htm].

Ricochet: »Freedom Isn't Free« (Single-CD, 2001) [Country].

Daniel Rodriguez: The Spirit Of America (CD, Feb. 2002) [Pop] [http://www. danielrodriguezmusic.com].

Kenny Rogers: »Homeland« (CD There You Go Again, Nov. 2001) [Country].

Kay Seamayer: »Let Freedom Ring (MP3, Sept. 2001) [Country] [http://www. kayseamayer.com/letfreedomring.htm].

SheDaisy: »Battle Hymn Of The Republic (Single-CD, 2002) [Country].

Brian Terrell: »Distant Glory« (Single-CD, 2002) [Country] [http://www.lilesnet. com/patriotic/music/distant_glory.htm].

Aaron Tippin: "Where The Stars And Stripes And The Eagle Fly« (Single-CD, Dez. 2001) [Country] [http://www.jayp.net/stars].

Randy Travis: »America Will Always Stand« (Single-CD, Okt. 2001) [Country].

Various Artists: God Bless America: A Collection Of Songs Of Hope, Freedom \& Inspiration (CD, 16.10.2001).

Tracks: Celine Dion: »God Bless America«, Bruce Springsteen: »Land of Hope and Dreams «, Mariah Carey: »Hero«, Tramaine Hawkins: »Amazing Grace«, Bob Dylan: "Blowin' In The Wind«, Simon \& Garfunkel: »Bridge Over Troubled Water «, John Mellencamp: "Peaceful World«, Billy Gilman: "There's A Hero", Frank Sinatra: »America The Beautiful«, Lee Greenwood: "God Bless The U.S.A.«, Pete Seeger: »This Land Is Your Land«, Gloria Estefan: »Coming Out Of The Dark«, Mahalia Jackson: »My Country 'Tis Of Thee«, The Mormon Tabernacle Choir: »The Star Spangled Banner«, Bill Withers: »Lean On Me«.

Phil Vassar: »American Child« (CD Autograph, Aug. 2002) [Country].

Hank Williams Jr.: »America Will Survive« (CD Almeria Club, Nov. 2001) [Country].

\subsection{Pro War Songs}

Banastre Tarleton Band: »Attack Iraq« (MP3, 2002) [Rock] [http://artists.mp3s. com/artists/510/banastre_tarleton_band.html].

The Bellamy Brothers: "Let's Roll America« (CD Redneck Girl Forever, Juli 2002) [Country].

Canibus: »Draft Me« (CD C True Hollywood Stories, Nov. 2001) [HipHop].

Cash \& Computa: »Ground Zero (In Our Hearts You Will Remain)« (Single-CD, Nov. 2001) [HipHop].

Charlie Daniels Band: »This Ain't No Rag It's A Flag« (Single-CD als Beipack zur CD The Live Record, Sept. 2001) [Country-Rock].

Charlie Daniels Band: »The Last Fallen Hero« (CD Redneck Fiddlin' Man, Juli 2002) [Country-Rock].

Flexxarally feat. Diehard: »War On The Terrorist...« (MP3, 2001) [West Coast] [http://artists.mp3s.com/artists/13/flexxarally.html].

Russ Grimm: »Roll On« (MP3, 2001) [Country] [http://www.geocities.com/ grimm_y2]. 
Jackyl: »Open Invitation (I Hate You Bin Laden)« (MP3, Okt. 2001) [Metal] [http:// www.rockmerollmejackylmeoff.com].

Toby Keith: "Courtesy Of The Red, White, \& Blue (The Angry American) (CD Unleashed, Juli 2002) [Country].

R. Kelly: »Soldier's Heart" (Single-CD, April 2002, auch April 2003) [R'n'B] (Proceeds from the sales of the single will be donated to Army Emergency Relief, an organization that provides financial assistance to active and retired soldiers and their families).

MC Hammer: »No Stoppin' Us« (CD Active Duty, Nov. 2001; RealPlayerVideo mit Doku) [HipHop].

Mystikal: »Bouncin' Back (Bumping Me Against The Wall)«(CD Tarantula, Dez. 2001; Video) [HipHop].

Neutronic Plague: »911 On 911« (MP3, 2002) [Rock] [http://www.musicbroadcast. com/neutron].

Pastor Troy: »Bless America« (CD Universal Soldier, Sept. 2002) [HipHop].

Neil Young: "Let's Roll« (Single-CD, Nov. 2001; CD Are You Passionate?, April 2002) [Rock].

Zoids: "Back To Baghdad« (MP3, Juli 2002) [Blues Rock] [http://artists.mp3s.com/ artists/63/zoids.html].

\subsection{Osama bin Laden / Taliban Songs}

A Lesbian Nomad: »Hey! Mr Taliban« (MP3, 2001) [Parodie Harry Belafonte: »The Banana Boat Song «] [http://artists.mp3s.com/artists/323/a_lesbian_nomad. html].

Johnny America: »I Wanna Barbecue Bin Laden« (MP3, 2001) [Country] [http:// www.geocities.com/jonnodonnis2000/TalibanTop10.html].

Bigfins: "The Taliban Can« (MP3, 2001) [Parodie Sammy Davis Jr.: »The Candyman Can«] [http://www.bigfins.com/taliban56.htm].

Cosmic Impressions...: »Osama Yo Momma (MP3-CD The Eagle's Pissed Off!!, 2002) [Electronica] [http://artists.mp3s.com/artists/131/cosmic_impressions.html].

Johnny Crass: »Bomb Osama« (MP3, 2001) [Pop] [http://www.johnnycrass.com].

Scott Crazy: »Taliban Two-Step« (MP3, 2001) [Metal] [http://artists.mp3s.com/ artists/328/scott_crazy.html].

DADS: »50 Ways To Get Bin Laden« (MP3, 2001) [Parodie Paul Simon: »50 Ways To Leave Your Lover «] [http://www.osama.be/sitemap2.htm].

De Bush Schiet Schijf: »The Taliban Can« (MP3, 2001) [Parodie Sammy Davis Jr.: »The Candyman Can «] [http://www.dreamerpage.nl/binladen.htm].

Digital Love Sausage: "Osama Yo Mama« (MP3, 2001) [Heavy Metal] [http://search. mp3.com].

Johnny Fubar: »Bin Laden's Cave« (MP3, 2001) [Parodie The Beatles: »Octopus's Garden «] [http://artists.iuma.com/IUMA/Bands/Fotojournalist/index-2.html].

The Graveyard Boogie Band: »Osama Yo Mama« (MP3, 2001) [Rock] [http://artists. iuma.com].

Larry E. Hubbard: »Osama« / »Taliban Scat« (CD Wanted Dead Or Alive, 2002) [Country Rock] [http://www.cdbaby.com/cd/larrygmm1?].

KapEye: »Osama Yo Mama« (MP3, 2001) ['Political Humor`] [http://search.mp3. com].

Toby Keith \& Scott Emerick: »The Taliban« (MP3, live in Bob and Tom Show 2001) [Country].

Killer Spam's Comedy Stuff: "I Wanna Bomb Osama (MP3, 2001) [Parodie »La Bamba«] [http://artists.mp3s.com/artists/12/john_mammoser.html]. 
KOMP Rock \& Roll Morning Show: »Osama Bin Laden Bomb Song (MP3, Okt. 2001) [Parodie Harry Belafonte: »The Banana Boat Song «] [http://www.osama.be/ sitemap2.htm].

KSEX Radio: »Osama Bin Laden Dead Or Alive« (MP3, 2001) [Parodie Bon Jovi: »Dead Or Alive«] [http://www.osama.be/sitemap2.htm].

Madcow: "Osama Yo Mamma« (MP3, 2001) [Death Metal] [http://search.mp3.com]. Naturally High: »Osama, I F*cked Yo Mama« I »Fartin' On Bin Laden« (MP3, 2001) [HipHop] [http://artists.mp3s.com/artists/243/naturally_high.html].

Noose: »Stick A M80 In Osama's Mouth « (MP3, 2001) [HipHop] [http://artists.mp3s. com/artists/222/noose.html].

Overflow2: »Osama Yo Mama« (MP3, 2001) [Punk/Ska] [http://www.garageband. com].

Pulsar: "Kill Bin Laden « (MP3, 14.9.2001) [Metal] [http://www.pulsarbeat.co.uk].

Pythonron \& His Flow Control Clones: »50 Ways To Kill Bin Laden« (MP3, 2001) [Parodie Paul Simon: »50 Ways To Leave Your Lover «] [http://politicalhumor. about.com/cs/osamasongs].

Johnny Rebel: »Infidel Anthem (F--- You, Osama Bin Laden!)« (Single-CD, 2002) [Country] [http://www.officialjohnnyrebel.com/new_page_3.htm; http://www. johnnyrebel.com/index.html].

Bob Rivers: »The Taliban Can« (MP3, 2001) [Parodie Sammy Davis Jr.: »The Candyman Can«] [http://www.b98fm.com/brettandtracy_special_music.html; http://www.twistedtunes.com].

STD'z (Sexually Transmitted Dopeness): "Afghani-Stan feat. Osama Bin Laden« (MP3, 2001) [Parodie Eminem: "Stan«] [http://www.soundclick.com].

Ray Stevens: »Osama - Yo' Mama (You In A Heap O' Trouble Boy)« (MP3, Okt. 2001; CD Osama Yo'Mama - The Album, 2002) [Country].

Taibo: "F*ck You Bin Laden« (MP3, 2001) [Hardcore Rap] [http://artists.mp3s.com/ artists/252/taibo.html].

The Ugly American: »Osama Bin Laden Loves Rap Music « (MP3, 2001) [HipHop] [http://artists.iuma.com/IUMA/Bands/Ugly_American].

Bret Walton: "Osama Run Home To Your Mama« (MP3, Dez. 2001; CD Remember The Roses, Jan. 2002) [Rock] [http://www.bretwalton.com].

Weird Al Yankovic: »Bin Laden Boat Song« (MP3, 2001) [Parodie Harry Belafonte: »The Banana Boat Song«].

\subsection{John Walker Lindh Songs}

Brenda Anzelc: »John Walker (MP3, 2002) [Alternative] [http://artists.mp3s.com/ artists/320/brenda_anzelc.html].

Ben Bochner: »Ballad Of Johnny Walker « (MP3, 2002) [Folk] [http://artists. $\mathrm{mp} 3 \mathrm{~s}$. com/artists/41/ben_bochner.html].

Capitol Steps: »Johnny's No Good« (MP3, 2002) [Parodie Chuck Berry: »Johnny B. Goode«] [http://politicalhumor.about.com/cs/johnwalker].

DJ Krush feat. Anticon: "Song For John Walker (CD Shinsou - The Message At The Depth, Sept. 2002) [HipHop].

Steve Earle: »John Walker's Blues« (CD Jerusalem, Sept. 2002) [Country-Rock].

Roy Edroso: »The Ballad Of John Walker Lindh (Kill Me) (MP3, 2002) [Country Rock] [http://www.alicubi.com/verse/johnwalker.html].

Billy Florio: "A John Walker Parody « [Parodie Steve Miller: »Take The Money And Run«] [http://www.amiright.com/parody/70s/stevemiller5.shtml].

Sonoma To Marin: »The Ballad Of John Walker Lindh« (Single-CD/MP3, 2002) [Pop] [http://artists.mp3s.com/artists/425/sonoma_to_marin.html]. 
TeleBAN: "John Walker: Taliban Ranger « (MP3-CD White Powder Not Included, 2002) ['Political Humor ‘] [http://artists.mp3s.com/artists/321/teleban.html].

Uncle Slim: »Johnny Walker Red« (MP3, 2002) [Alternative Country] [http://artists. $\mathrm{mp} 3 \mathrm{~s} . \mathrm{com} /$ artists/248/uncle_slim.html].

\subsection{Anti War Songs}

Anti-Flag: »911 For Peace« (CD Mobilize, Feb. 2002) [Punk-Rock] [http://www. anti-flag.com/anti-flag].

Dan Bern: »Talkin' Al Kida Blues« (EP The Swastika, 2002) [Folk] [http://www. danbern.com/swastika.html\#alkida].

Jello Biafra: »The Big Ka-Boom, Part 1« (CD, live 14.11.2001) [Punk-Speech].

Darryl Cherney \& the Chernobles: »Bush It! « / »Send George Bush A Pretzel « (Single-CD, 2002) [Rock] [http://bushandcheneysuck.com/Bushit.htm].

Chuck D: »No Boom Booms (MP3, 2002) [HipHop, Parodie John Lee Hooker: »Boom Boom«] [http://www.slamjamz.com].

Country Bumpkin \& The Hogs: »The Iraqi War Song - Feel Like I'm Smellin' A Rat Rag «(CD-Single/MP3, Sept. 2002) [Parodie Country Joe McDonald: »l-Feel-LikeI'm-Fixin'-To-Die-Rag«] [http://www.healingcelebrations.com].

Dead Prez: »Know Your Enemy« (CD Turn Off The Radio, Nov. 2002) [HipHop].

Demonstrators: »Baghdad Boogie« (MP3, 2002) ['Political Humor`] [http://artists. mp3s.com/artists/133/demonstrators.html].

Ani DiFranco: "Self Evident« (CD So Much Shouting, So Much Laughter, Sept. 2002) [Alternative].

Dj Thug World Order: »USA vs IRAQ« (MP3, 2002) [HipHop] [http://artists.mp3s. com/artists/505/dj_thug_world_order.html].

The Dope »Poet Society: 911: World Trade« (EP, 2001) [HipHop mit Doku] [http:// www.justusleaguerecords.com/worldtradepage.htm].

Clan Dyken: "911 (This World Gone Crazy)« (CD Love Is, 2002) [Folk-Rap] [http:// www.clandyken.com/Music_Lyrics/music_lyrics.htm].

Emcee Lynx: "Profound Things (In The Aftermath...) (CD Soundtrack For Insurrection Volume Two, 2002) [HipHop] [http://www.circlealpha.com/ soundtrack.html].

L. A. Estridge: »Unholy War« (RealAudio, 2001; CD Unholy War) [Folk] [http://laegallery.com/unholy/index.html].

Eye: »Taliban, Made By The USA« (MP3, 2002) [Alternative HipHop] [http://artists. mp3s.com/artist_song/2049/2049992.html].

Fine Arts Militia (FAM): »A Twisted Sense Of God (Pt.1 / Pt.2)« (CD We Are Gathered Here..., 2002) [HipHop] [http://www.fineartsmilitia.com].

Flying Folk Army: »Uncle Sam« (MP3, 2002) [Folk] [http://www.flyingfolk.ca; http://www.tao.ca].

John Flynn: »I Will Not Fear « (CD To The Point, bonus track, 2001) [Country Rock] [http://www.johnflynn.net/lyrics/tunes/point/i_will_not.htm].

Robin Foreman: "Let's Bomb Iraq" (MP3, 2002) ['Political Humor<] [http://artists. $\mathrm{mp} 3$ s.com/artists/525/robin_foreman.html].

Sage Francis: »Makeshift Patriot « (Vinyl-Single, Dez. 2001) [HipHop].

Michael Franti \& Spearhead: »Bomb The World« / »Bomb The World (Armageddon Version)« (MP3, komp. Sept. 2001) [Rock/HipHop-Reggae] [http://www. spearheadvibrations.com].

Ginger Tom: »Hey-Hey, USA: How Many Children Did You Kill Today?« (MP3, 2002) [Indie] [http://www.mp3.com.au/track.asp?id=32711]. 
Godspeed You Black Emperor!: »Rockets Fall On Rocket Falls« (CD Yanqui U.X.O., Dez. 2002) [Indie Rock] [http://media.salon.com/mp3s/godspeed010703.mp3].

Kevin Healey: "Cruise Missiles For Brains « / »Puppet Flags« / "Dirty Umbrella« (CD Puppet Flags, Mai 2002) [Folk] [http://www.picassos-crayon.com/home.html].

Peter Hicks: "So Many Tears, So Many Flowers« (MP3 2002; CD One World Is Not For Sale, 2003) [Folk] [http://www.trump.net.au/\%7Eglazfolk/songs/tears.htm].

Jahi: »Neva The Same« (MP3, 2002) [HipHop] [http://www.daveyd.com/ audiochambers.html].

Wyclef Jean: »War No More« (CD Masquerade, Juni 2002) [Reggae].

Jihad Against America [Australien]: »Jihad Against America« / »Terrorism Is The New Black« / »Holiday In Manhattan« (Single-CD/MP3, 2002) [Punk/Rock/ Hardcore] [http://www.jihadagainstamerica.com].

J-Live: "Satisfied " (CD All Of The Above, April 2002) [HipHop].

Robb Johnson: »3 Minutes' Silence / »In November / »Peace At Last« (Dez. 2001) [Folk] [http://www.robbjohnson.co.uk].

Robb Johnson: "Stop the War / / "Summertime \# 2 (Don't Mourn, Organise) (Sept. 2002) [Folk] [http://www.robbjohnson.co.uk].

Junoon [Pakistan]: »No More (CD-Single/Video, Sept. 2002) [Sufi-Rock] [http:// www.junoon.com/home2.htm].

Kast-One: »9-1-1 (9-11-01 Tragedy)« (MP3, 2001) [HipHop] [http://artists.mp3s. com/artists/294/kast-one.html].

Known Associates feat. Lord Jamar, Shabazz The Disciple \& Star Bliddack: »World So Cold « (Vinyl-Single, März 2002) [HipHop].

Talib Kweli: »The Proud« (CD Quality; Nov. 2002) [HipHop].

Lawnmower R'n'B: »No More War Blues« (MP3, 2002) [R'n'B] [http://polsong.gcal. ac.uk/Lyrics/no_more_war_blues.htm].

Sara Marlowe: »When Will The Madness End?« (CD A World to Win, 2002) [Folk-Pop] [http://www.worldtowin.org].

John McCutcheon: »Follow The Light« / »Not In My Name« (komp. Sept./Okt. 2001; CD The Greatest Story Never Told, Red House 163) [Folk] [http://www. folkmusic.com/record/r_story.htm].

John McCutcheon: »Talking Pat And Jerry Blues« / »The List« (MP3, komp. 16.9. 2001 / 19.9.2001) [Folk] [http://www.folkmusic.com/t_mp3.htm].

John McCutcheon: »Ashcroft's Army (Version 2)« (MP3, komp. 12.8.2002) [Folk] [http://www.folkmusic.com/t_mp3.htm].

George Michael: "Shoot The Dog« (Single-CD/Video, Aug. 2002) [Pop].

Mr Lif: "Home Of The Brave (CD Emergency Rations, Juni 2002) [HipHop].

Briege Murphy: »Aoife's Worries" (CD The Elm Wood, 2002) [Folk] [http://www. chivalry.com/briegemurphy/elm_wood.html].

Nas feat. Amerie: »Rule / »What Goes Around« (CD Stillmatic, Dez. 2001) [HipHop].

Meshell Ndegeocello: "Forgiveness \& Love« (MP3, Feb. 2003, komp. 2001) [HipHop/R'n'B] [http://www.meshell.com/forgiveness_and_love.html; http:// www.freemyheart.com/portia.html].

Norway \& the NJ All-Stars: »Bridge Of Faith « (CD United - We All Come Together, 2002) [Pop] [http://www.norwayrocks.com/united.htm].

Leslie Nuchow: »An Eye For An Eye (Will Leave The Whole World Blind)« (Single-CD, 2001) [Folk] [http://www.cdbaby.com/cd/nuchow3/from/neatness].

Yoko Ono: "Give Peace A Chance 2002« (MP3, Okt. 2002) [http://www. mindtrainrecords.com/listen].

Onyx: »Feel Me« (CD Bacdafucup Part II, Juli 2002) [HipHop]. 
Jim Page: »Who Are They And Do They Hate Us?« (CD Collateral Damage, 2002)

[Folk] [http://www.cdbaby.com/cd/jimpage4; http://jimpage.net].

Paris: "What Would You Do?« (MP3/Single-CD, März 2002; CD Sonic Jihad, Juli 2003)

[Guerrilla-Funk mit Bush-Doku-Fake]

Public Enemy: »Son Of A Bush« (CD Revolverlution, Juli 2002) [HipHop].

Residue: »Iraquet « (MP3, Nov. 2002) [Hardcore Punk] [http://committed.to/ residue; http://artists.mp3s.com/artists/428/residue1.html].

David Rovics: »The Dying Firefighter « / »International Terrorists « (komp. 11.9. 2001) (MP3-CD Living In These Times, 2001) [Folk] [http://www.davidrovics. com; http: / / www. soundclick.com/pro/?BandID=111310].

David Rovics: »The Next Attack « / The Village Where Nothing Happened / »Bomb Ourselves « (MP3-CD Hang A Flag In The Window, Sept. 2002) [Folk] [http:// www.davidrovics.com; http://www.soundclick.com/pro/?BandID=111310].

The Savage Rose: »A World Aflame (Not In Our Name) New Mix« (MP3, Okt. 2002) [R'n'B] [http://www.thesavagerose.com; http://artists.mp3s.com/artists/311/ savage_rose.html].

Jan Seides: "To Give Us Peace (MP3, 2001) [http://www.janseides.com/ ForSeptember11th.html].

Seize The Day: »United States« (MP3, 2002) [Folk] [http://www.seizetheday.org/ UnitedStates.htm].

Shine: "Peace Anthem (Not In Our Name) (CD Shine with the Pacifica Radio Archives - Not In Our Name, Dez. 2002) [Folk] [http://www.unitynetwork.net/ shine; http://www.rpursuit.com/shine; http://www.actionsf.org/shine.htm].

Keith Shugarts: »I Don't Want To Be A Good Citizen« (2001) [http://polsong.gcal. ac.uk/Lyrics/Good\%20Citizen.htm].

Stephan Smith (with Pete Seeger, Dean Ween, and Mary Harris): "The Bell« (EP, Sept. 2002) [Folk] [http://www.stephansmith.com/audiovideo.html].

Paul Stein: »Not In Our Name!« (MP3, 2002) [Folk] [http://www.notinourname.us/ pages/1/index.htm].

James Taylor: »Belfast To Boston (God's Rifle)« (CD October Road, Aug. 2002) [Rock].

Various Artists: House Music Against War (EP, Sept. 2002) [House] [http://www. handontheplow.com].

Tracks: L. Beckett: »What To Do?«, Project Brothers: »We're All You Know«, O. Miller: »Baghdad 1991«.

Various Artists: Peace Not War (Doppel-CD, 9.12.2002) [http://www.stopwar.org. uk/cd.asp; http://www.peace-not-war.org].

Tracks: Ani DiFranco: "Self Evident«, Public Enemy: "Son Of A Bush«, Midnight Oil: »US Forces « (1983), DJ DisOrientalist: »Occident \& Emergency«, Ginger Tom: »Hey Hey USA «, Seize The Day: »United States«, Fun<da>mental: »Rape (Tactic Of War)«, The Unpeople: »The Unpeople (John Pilger Remix)«, Crass: "Nagasaki Nightmare (1980), Slovo: »21 Today«, The Mark of Cain: "Lone Pine (2001), Change: »We Want A Ceasefire«, Billy Bragg: »The Price Of Oil«, Massive Attack: »Hymn Of The Big Wheel (1991), Ms. Dynamite: »Watch Over Them«, GM Babyz: "Pain Of Life«, Roots Manuva: »Juggle Tings Proper (1999), Chumbawamba: "Jacob's Ladder (Not In My Name)«, Alabama 3: »Woody Guthrie«, Laszlo Beckett: "What To Do«, Torben \& Joe: »Money Is Your Blood«, Gurlfiend: "Spark Of Life«, Tariq Ali (Asian Dub Foundation Remix): »Not In Our Name «, Persian Carpets: »Allah Save Queens«, Mud Family: "Peace Not War «, John Lester: »Out Of The Clear Blue Sky«, Pok \& the Spacegoats: »Voices Of A Future (1999), Nitin Sawhney: »Cold And Intimate (2001), Coldcut: »Atomic Moog (Cornelius Mix)« (1998), Sia: »Fear« (2000), Bindi Blacher: »Down« (1999). 
Hanifah Walidah: "Soldier Man« (CD War Times, Dez. 2002) [HipHop] [http://www. trustlife.net/crookaletta/crookalettas.html; http://www.daveyd.com].

Jennifer Warnes (feat. Arlo Guthrie): "Patriot's Dream« (CD The Well, 2002) [jenniferwarnes.com].

Sol Weber: "September 11 (2001, auf CD von Sing Out, Winter 2002) [http:// www.singout.org/454toc.html].

Paul Weller: "A Bullet For Everyone« (CD Illumination, Sept. 2002) [Rock].

David Wilcox: »Hymn For The Highway« / »September 12th« (MP3, 2002) [Folk] [http://artists.mp3s.com/artists/154/david_wilcox.html].

David Wilcox: »A Different Kind Of War« (MP3, 2001, live 12.1.2003 at E-Town) [Spoken Words] [http://www.whatarerecords.com/dw/war/index.html].

Saul Williams: »Bloodletting / $»$ September 12th « (EP, Okt. 2002) [HipHop] [http: //www.notinournamemusic.com/home.php; http://www.notinourname.net].

Saul Williams: »Not In My Name - Pledge Of Resistance (MP3, 2002) [Spoken Word] [http://www.notinournamemusic.com/home.php].

David Yarborough: »Bushit « (MP3, 2002) [Folk] [http://www.croftononline.com/ bushit.html].

Yo La Tengo: »Nuclear War « (4 versions of Sun Ra's »Nuclear War «) (Maxi-CD, Nov. 2002) [Indie Rock] [http://www.peace-not-war.org/Music/YoLaTengo/index. html; http://www.audiogalaxy.com/pages/review.php?band_id=108628].

\subsection{Songs aus der BRD und Österreich}

64er DJ Andi: »11th September« (MP3, 27.9.2001) [Trance] [http://www2.mp3.de/ musik/bands/de/2/8804?param $=$ I].

Christian Anders feat. Jenna Kartes: »Der Tag, an dem die Erde still stand (The Day The World Stood Still)« (Maxi-CD, März 2002) [Pop] [http://www. christiananders.net/wtcetextf.htm].

And One: »Amerika brennt « (MP3, 15.9.2001) [Doku-Remix] [www.andone.com/ Amerika_Brennt.mp3].

ARIS feat. Yasmin: "Stand Together (September 11th 2001)« (MP3, 2001) [Pop] [http://artists.iuma.com/IUMA/Bands/ARIS_Rock/index-1.html].

Brach Verwesung: »don't call bin laden islamic rübezahl« (MP3, 1.1.2002) [Noise] [http://www2.mp3.de/musik/bands/de/2/136016?param=|].

CJ-Spooky: »Black Tuesday (Against Terror Remix)« (MP3, 15.9.2001) [Trance] [http://www2.mp3.de/musik/bands/de/2/1658?param=|].

Curse: »Nichts wird mehr so sein wie es war (MP3, 16.9.2001) [HipHop] [http:// www.curse.de/single2001/terror.html].

Funny van Dannen: »11. September «(CD Groooveman, 30.9.02) [Dt. >Schlager ‘].

DeeJay Dee: »Terror in Amerika (MP3, 13.9.2001) [Techno] [http://www2.mp3. $\mathrm{de} /$ musik/bands/de/2/1909?param=I].

Franz Josef Degenhardt: "Quantensprung« (CD Quantensprung, 20.8.2002) [Liedermacher] [http://www.franz-josef-degenhardt.de].

Die Firma: "Kein Ende in Sicht« (EP Hör Ma, 7.1.2002; CD Das Dritte Auge, 4.2.2002) [HipHop].

Die komplette Bandbreite: »Mister Bush « (MP3, 23.10.2001) [HipHop] [http://www. diekomplettebandbreite.de; http://www.wojna.de/mp3/mp3.html].

Diska: America's The Bomb (CD, 11.9.2002) [ElectroPop].

DJ LangSKy: "Thank U! (I Can Hear You)« (MP3, 2001) [House mit Doku] [http:// mp3-katalog.dino-online.de/010/User/0,4470,g0r0l1t0o1i236792,FF.html].

DJRC (djrchrome): »America Under Attack« (MP3, 14.9.2001) [Trance mit Doku] [http://www2.mp3.de/musik/bands/de/2/4213?param=|]. 
Klaus-André Eickhoff: „God Bless America“ (CD Höhenflug, 2002) [Christl. Liedermacher] [http://www.ka-eickhoff.net].

Freistilschwimmer: »DJ Saddam ft Osama MC« (MP3, 27.9.2002) [HipHop] [http:// www2.mp3.de/musik/bands/de/2/168451?param=I].

Charlie Glass \& Nera: "Save The World (MP3, 2001) [Pop] [http://www. weltfriedensong.de].

Groove Girl: »In Memory Of The 11. September 2001 (MP3, 16.7.2002) [Dance mit Doku] [http://www2.mp3.de/musik/bands/de/2/145336?param=I].

Helium Brothers: »Inventur im World Trade Center « (MP3, 2002) [HipHop] [http:// www.whimpsplasher.de/inventur.html; http://www.besonic.com/User/0,1391, g0r0l1t0o0i201901,FF.html].

Highbeat-Project: »Memorial of the 11th September 2001« (MP3, 10.9.2002) [Trance mit Doku] [http://www2.mp3.de/musik/bands/de/2/105040?param=I].

Jack Junk Dean: »America (Stars and Stripes Remix) (MP3, Okt. 2002) [HipHop] [http://www.shining-hiphop.de/junker.htm].

Ketti ft DeeJane: »Afghanistans [sic] Terror Will Not Survive« (MP3, 15.12.2001) [House mit Doku] [http://www2.mp3.de/musik/bands/de/2/120788?param=|].

Thomas Liebe: »Wo ist Bin Laden jetzt (CD Allen soll es gut gehn, 2002) [Grunge] [http://www.thomasliebe.de/cds.html; http://www.besonic.com/User/0,1391, g0r0l1t0o0i71611,FF.html].

Modee aka Mode On My E [Österreich]: »No War (MP3, Dez. 2002) [HipHop] [http://fm4.orf.at/soundpark/m/modeeakamodeonmye].

Nuemmes: „New War - Nein Song (MP3, Okt. 2001) [Rock] [http://www. nuemmes.de/songs/texte/new_war.html].

Quadstone: »Warum? (scheiss krieg)« (MP3, 14.10.2001) [Trance] [http://www2. $\mathrm{mp3}$.de/musik/bands/de/2/60729? param $=\mid$ ].

realsounds / frei: »We Will Win (11 Sept 2001)《 (MP3/Flash-Animation, 2002) [Pop mit Doku] [http://www.realsounds.de; http://www.bestsong.de].

Rowdy Club: »Wissen was geht « (Live-Version; The Rowdy Club - Das Tape, Dez. 2002) [HipHop] [http://www.40below.de:8080/go/home/music/reports/wissen_ was_geht.html; http://www.zughafen.de].

Josef Saddler: »America At War« (MP3, 2002) [Deep House] [http://www.besonic. com/User/0,1391,g0r0l1t0o0i145723,FF.html].

Sandalette: »Die Kinder von Bin Laden (MerryXmasEdit)« (MP3, Dez. 2001) [TripHop] [http://www. besonic.com/User/0,1391,g0r0l1t0o0i608719,FF.html].

Symbioose: "Was kann ich tun « (CD more than before, 2001) [Pop] [http://www. symbioose.de/news/Was_kann_ich_tun.mp3].

Syncmode [Österreich]: »War (MP3, 21.9.2001) [Electronic mit Doku] [http:// www.artfusion.at/syncmode/trax/WAR.mp3].

Thunder / Chris Mike: „Darkness Of Sept. 11« (Single-CD, 2001) [Instr. Pop] [http://www.thunderthelegend.com; http://www.chrismike.com].

Versbox: »Lied des Friedens« (MP3, 22.9.2001) [HipHop] [http://versbox.info/vers. box/musik/kommerz].

Vision Blue, DJ Grandfather \& Simon The Bassdrum: America 11 September 2001 The Memorial Album (MP3-CD, 2001) [Techno] [http://remember.worldatwar. org/schwarzewochen/songs.htm].

Tracks: »11 September 2001 (Beginning And End Of All Time)«, »America; We Cry With You (Voices Remix)«, "Against Terror «, "Against Terror (Cockpit Remix)«, »Against Terror (The Rave)«, »Wanted - Dead Or Alive «, »Heroes For Liberty«, »All Hearts To Strike«, »Back To Peace (Home On The Range)«, "America, We Cry With You (Maxi Version)«.

Wolf \& Gang: »Jetzt« (RealAudio, Sept. 2001) [Pop] [http://www.bairischesprache.de/ramadan.html]. 


\section{Januar - Mai 2003 (...Irakkrise, Irakkrieg)}

\subsection{Pro War Songs}

Clint Black: »I Raq And I Roll« (MP3, 11.3.2003) [Country Rock] [http://www. clintblack.com/songlyrics.html].

David DiLeo: »A Brother's Song (MP3, Feb. 2003) [Pop] [http://www.daviddileo. com].

Eddie Three Eagles: Red, White \& Blue (Dedicated to our Fighting Men and Women) (CD, April 2003) [Native American Music] [http://www.iraqifreedom.us; http:// www.aancorecords.com/eddie_music.htm].

Tracks: »My Heart, My Soul, My Music«, »Red, White and Blue «, »Where Have All My People Gone«, "Spirit Song«, "Follow The North Star «, »Tashunkewitko«, »I Will Fight No More Foreve«, »Wipe Away The Clouds«, "Spirit Of Running Hawk«, "Apache Rain«, "Song Of Three Eagles«, »On The Wings Of The Eagle«.

Larry Hagen Jr.: »It Could Be Me« (MP3, April 2003) [Country] [http://www. larryhagenjr.com/downloads.htm].

Jalyia: »Freedom« (Single-CD/MP3, April 2003) [Pop] [http://jalyia.com; http:// www.operationiraqifreedom.com/jalyia.htm].

R. Kelly: "Soldier's Heart « (Single-CD, April 2003, auch April 2002) [R'n'B].

Omar \& the Sandcrabs: »The Ballad of Saddam Hussein« (MP3, 1991, reissued 2003) [Country] [http://artists.mp3s.com/artists/329/omar_the_sandcrabs.html].

SLABB: "Saddamn Inssein« (MP3, Feb. 2003) [Rock] [http://www.garageband.com/ artist/slab].

Vince Vance \& The Valiants: "We Don't Run« / "Yakety Yak Bomb Iraq" (CD We Don't Run / FlashAnimation, März 2003) [Parodie The Coasters: "Yakety Yak«] [http://www.stevebellas.com/vince_vance.html].

The Warren Brothers: »Hey, Mr. President « (Single-CD, März 2003) [Country].

Darryl Worley: »Have You Forgotten« (Single-CD, Feb. 2003) [Country] [http:// www.darrylworley.com].

\subsection{Anti War Songs}

Shaaban Abdel-Rehim [Ägypten]: »Al-dharb fel Iraq (Attack On Iraq)« (Single-CD, Feb. 2003) [Egypt-Pop] [http://songs2.6arab.com/sha3ban-3abdelra7eem.. eldarb-fel-iraq.ram].

The Abstractions: »War After War (CD Ars Vivende, Jan.-März 2003) [Alternative] [http://www. sonicyouth.com/prmp3/War_After_War.mp3].

Adventurous Adam [UK]: »War On Iraq« (MP3, Jan.-März 2003) [Hardcore Techno mit Doku] [http://www.mp3.com.au/track.asp?id=42941].

Afurnishedsoul [Schottland]: »War Among Us« (CD-EP Hope's An Open Window, Feb. 2003) [Post-Punk] [http://afurnishedsoul.cjb.net].

De Amsterdam Klezmer Band met Bob Fosko [Holland]: »Gevaarlijke man « (MP3, Feb. 2003) [Klezmer] [http://www.amsterdamklezmerband.nl; http://www.jp.nl/nieuws/nieuws.html].

Joyce Andersen: "Filled With Love« (MP3, März 2003) [Folk] [http://www. joyscream.com/peace.html].

Anti Flag \& Donots: »Protest Song« (MP3, Feb. 2003) [PunkFolk] [http://www.antiflag.com/MU40.php]. 
The Anti-Idiot-President Coalition: »Hey Mr President, Don't You Kill For Me! « (MP3, Jan.-März 2003) [Blues Rock] [http://artists.mp3s.com/artists/542/the_antiidiot-president_c.html].

Billie Joe Armstrong [von Green Day]: »Life During Wartime« (MP3, März 2003) [Acoustic Rock, Cover Pinhead Gunpowder: »Life During Wartime«] [http:// www.officialgreenday.com/home.php3].

Articles Of Faith: »Buy This War (EP Fortunate Son, Jan.-April 2003) [Punk] [http://www.alternativetentacles.com/product. php?product=570\&sd=ECbyZBdc zZf3a50mA80].

Asian Dub Foundation: »Enemy Of The Enemy« (CD Enemy Of The Enemy, Feb. 2003) [HipHop].

Assalti Frontali [Italien]: »|l mio miglior inganno (Baghdad Baghdad) « (MP3, März 2003) [HipHop] [http://www.ondarossa.info/audio/assalti.mp3].

avandguard: »Burn Baby Burn (Protest War In Iraq)« (MP3, Jan.-März 2003) [Indie] [http://artists.iuma.com/IUMA/Bands/avandguard].

Beastie Boys: »In A World Gone Mad...« (MP3, März 2003) [HipHop] [http://www. beastieboys.com].

Big Mo \& The Full Moon Band: »This Ain't No Cause« (MP3, März 2003) [Pop] [http://www.bigmoblues.com/blues].

Luka Bloom [Irland]: »I Am Not At War With Anyone« (MP3, Feb. 2003) [Folk] [http://www.lukabloom.com/news_gigs.asp; http://home.knuut.de/e_r_ bergholz/lbloom/lyrics/iamnotatwar.htm].

Everton Blender [Jamaika]: »Bush And Saddam« (MP3, März 2003) [Reggae] [http:// www.acroots.com/roots/news.htm].

James Blundell [Australien]: »Back It Up« (MP3, März 2003) [Country] [http://www. jamesblundell.com.au].

Michael Borkson: »No War On Iraq« (MP3, März 2003) [Folk Rock] [http://artists. iuma.com/IUMA/Bands/Michael_Borkson].

Jim Boyd \& Kyo-T: »Bush Fires (MP3, Feb. 2003) [Folk Rock] [http://artists.iuma. com/IUMA/Bands/Jim_Boyd_KyoT; http://www.thunderwolfrecords.com].

Jonatha Brooke: »War« (MP3, März 2003) [Folk Rock] [http://jonathabrooke.com/ war].

Bush Remixed: »Decisive Force (New Version - March 28)« (MP3, März 2003) [BushDoku-Mix] [http://www.planetarycouncil.com/decisiveforce.php].

George W. Bush \& Matt Rogalsky: "Two Minutes Fifty Seconds Silence For The USA « (MP3, März 2003) ['Silences« von George W. Bushs »Address to the World«, 17.3. 2003] [http://mrogalsky.web.wesleyan.edu/gwb170303].

Chris Brown \& Kate Fenner [Kanada]: »Resist War (MP3, Feb. 2003) [Folk] [http://www.resistwar.com].

Dennis Caraher: »Bomb Around The Clock« (MP3, Feb. 2003) [Parodie "Rock Around The Clock«] [http://artists.mp3s.com/artists/549/dennis_caraher.html].

Paula Cole: »My Hero, Mr. President!« (MP3, Jan. 2003) [Folk Rock] [http://www. paulacole.com/news].

The Compassionate Conservatives: "Another War (MP3, Feb. 2003) [Parodie The Beatles: "Drive My Car «] [http://www.iuma.com/IUMA/Bands/The_ Compassionate_Conservatives].

The Compassionate Conservatives: »In The Garden Of Eden« (1: War Crimes/DC Rally Mix; 2: Zinn/Fisk/Nader Remix) (MP3, Feb. 2003) [Parodie Iron Butterfly: »In-A-Gadda-Da-Vida« mit Doku] [http://www.iuma.com/IUMA/Bands/The_ Compassionate_Conservatives]. 
The Compassionate Conservatives: »Midnight Confessions (Of Emporer G. W. Bush)《 (MP3, März 2003) [Parodie The Grassroots: »Midnight Confessions « mit Doku] [http://www.iuma.com/IUMA/Bands/The_Compassionate_Conservatives].

The Contraband: "Six Million Dollar Man« (CD Natural Born Killers (the truth and lies about 9/11), März 2003) [Punk] [http://www.wordgroove.com/contraband/ music.html].

Coolplay [UK]: »Green Guys« (MP3, April 2003) [Parodie Coldplay: »Green Eyes«] [http://www.coolplay.co.uk/greenguys.htm].

Corpesus: »Bush Over Baghdad (Blood For Oil)« (MP3, 2003) [Alternative] [http:// artists.mp3s.com/artists/164/corpesus.html].

Cosmic Nomads [Australien]: »Make Love Not War« (Single-CD/MP3, März 2003) [Rock] [www.cosmicnomads.com].

Crucial Crew [Holland]: »We Want Peace (No More War)« (1: Original Ragga Riddim Demo / 2: Dub Version by Pat Flashman) (MP3, März 2003) [Reggae] [http://home2.pi.be/patkarla/Crucial\%20Crew.htm].

Da [Spanien]: »Ay Esperanza« / »En Guerra« / »Que Se Jodan« (MP3, März 2003) [HipHop] [http://www.walnutdoor.net].

Danger Mouse \& Jemini: »Bush Boys« (MP3/Video, März 2003) [HipHop mit Doku] [http://www.djdangermouse.com].

Kimya Dawson: "Anthrax« (MP3, Jan.-März 2003; CD My Cute Fiend Sweet Princess, Sep. 2003) [Anti-Folk] [http://www.kimyadawson.com; http://www.sonicyouth. com/prmp3/anthrax.mp3].

Michael DeMarco: „War Song“ (MP3, Jan.-März 2003) [Folk] [http://www. mindgrove.net/song.html].

John Robin Devany: »'m Getting Ready For World War 3« (MP3, Feb. 2003) [Folk] [http://www.soundclick.com/bands/2/johnrobindevanymusic.htm].

Digital Cutup Lounge [Stephen and John von Seggern]: »Drop Bush Not Bombs« (MP3, März 2003) [Techno-Mix] [http://www.digitalcutuplounge.com/audio_ video/Digital_Cutup_Lounge-Drop_Bush_Not_Bombs.mp3].

Johnny Dixon: »| Don't Understand« (MP3, März 2003) [Country] [http://www. nationalvanguard.com/israel].

Dj Reis: »Fuck Bush« (MP3, März 2003) [Electronic mit Doku] [http://www.arizona. indymedia.org/news/2003/03/9132.php].

D-LIRIOUZ [Frankreich]: »Bush In Da Jungle« / »Washington's Cowboy« (MP3, März 2003) [D'n'B mit Doku] [http://perso.wanadoo.fr/d-liriouz].

Terry Dobbin: »Uprising F15« (MP3, Feb. 2003) [Techno] [http://artists.iuma.com/ IUMA/Bands/Terry_Dobbin/index-2.html; http://www.terrydobbin.com].

David Dondero: »Pre-Invasion Jitters« (MP3, März 2003) [Folk] [http://www. futurefarmer.com/hear.html]

The Dope Poets Society [Kanada]: »War Of Terrorism« (Single-CD, Feb. 2003) [HipHop] [http://www.justusleaguerecords.com].

Steve Durfee: »We Don't Want No War« (MP3, Feb. 2003) [Country] [http://polsong. gcal.ac.uk/itemaudio/WeDon'tWantNoWar.mp3].

The Evens: »On The Face Of It« (MP3, Jan.-März 2003) [Alternative] [http://www. sonicyouth.com/prmp3/ON_THE_FACE_OF_IT.mp3].

Roger Filip [Holland]: »Let's Start Again!« (MP3, März 2003) [Pop] [http://www. motherearth.org/nowar/resources/roger.mp3].

Fleetwood Mac: »Peacekeeper« (MP3, März 2003; CD Say You Will, April 2003) [Pop] [http://www.fmlegacy.com/News.htm].

Alan Fletcher [Australien]: »Perfectly Comfortable« (MP3, März 2003) [Pop] [http://alanfletcher.net/peace/index.html]. 
Foreign Policy: »Bridge For Peace« (MP3, Feb. 2003) [Rock] [http://www. bridgeforpeace.com].

FunkSpace.com: »Fight The Corruption« (MP3, März 2003) [Techno-Funk] [http:// www. funkspace.com/corruption.html].

Bob Frank: »Whoever Listens To The Lamb?« (MP3, März, 2003) [Folk] [http://www. bobfranksongs.com/pages/whoeverlistenstothelamb.html].

David Freyer \& the Positive Chi Units: »Rise Up« (MP3, Jan.-März 2003) [Pop mit Doku] [http://polsong.gcal.ac.uk/Lyrics/rise_up.htm].

Giants Against War \& MT Freeman: »Peace Welcome (MP3, Feb. 2003) [Folk] [http://polsong.gcal.ac.uk/itemaudio/gaw_and_mt_freeman_peace_welcome. mp3; http://belgium.indymedia.org/news/?category=\&medium=audio].

Nanci Griffith: »Big Blue Ball Of War (MP3, 17.3.2003) [FolkPop] [http://www. nancigriffith.com].

The Gushers: "Operation Desert Son (MP3, Feb. 2003) [Parodie Country Joe McDonald: »Fixin-To-Die..."] [http://www.mainepublicradio.org/asx/song.asx].

Harmonious Combustion: »This Is My Song «bzw. »A Song Of Peace (MP3, März 2003) [A Cappella] [http://www.art101.com/peace; http://www.sonicyouth. com/prmp3/peace.mp3].

Andrei Hauk: "Descendant « (MP3, Jan.-März 2003) [Rock] [http://www. garageband.com/artist/Andrei_Hauk].

Heideroosjes [Holland]: »Meneer de President« (MP3, März 2003) [Rock] [http:// www.heideroosjes.com/multimedia/Heideroosjes\%20-\%20Meneer\%20de\%20 President.mp3].

Peter Hicks [Australien]: »Faces In The Dark« (MP3, Feb. 2003) [Folk] [http://www. trump.net.au/ glazfolk/songs/faces.htm].

House of Velvet: "No More War « (MP3, 2003) [Pop] [http://www.houseofvelvet. com/nomorewar.htm].

Pat Humphries \& Sandy Opatow: „CodePINK For Peace!!« (Single-CD/MP3, März 2003) [Rock] [http://www.pathumphries.com; http://www.codepink4peace. org].

Insane ILLneSs: »War On Iraq « (MP3, Jan.-März 2003) [HipHop] [http://artists.iuma. com/IUMA/Bands/Insane_ILLneSs/index-2.html].

Iron Sheik: »The Oil Anthem« (MP3, März 2003) [HipHop] [http://www.ironsheik. biz/oilanthem.html].

The John Kaspar Band: »We're The Enemy « (MP3, Jan.-März 2003) [Rock] [http:// www.garageband.com/artist/thejohnkasperband].

Robb Johnson \& The Rhythms of Resistance Samba Band: "Stop The War « (MP3, live Feb. 2003) [Folk] [http://www.peace-not-war.org/Music/RobbJohnson/index. html].

Robb Johnson: »The Day We All Said Stop The War« (MP3, März 2003) [Folk] [http://www.robbjohnson.co.uk].

Mick Jones \& Tony James: »Why Do Men Fight (MP3, Feb. 2003) [Rock] [http:// www.poptones.co.uk/news.shtml; http://www.esmark.net/bad/bad.htm].

Sarah Jones: »Who's War?« (MP3, März 2003) [HipHop] [http://www.hiphopmusic. com/archives/000031.html].

Judith [Holland]: »Fools Rule The World« (MP3, März 2003) [Pop-Rock] [http:// www.euronet.nl/users/lambooij-av/judith_english.htm].

Jynkz: »We Don't Want Your War« (MP3/Flash-Video, Feb. 2003) [Folk Rock] [http://www.jynkz.com].

Jynkz: »Rapt In A Chain Of Violence« (MP3/Flash-Video, März 2003) [Folk Rock] [http://www.jynkz.com]. 
Raheel Kamal: »The Game In The Name Of Peace« (Video, März 2003) [Instr. Rock] [http://www.raheelkamal.com].

De Kanunniken [Holland]: »Oliedom (Oily-Stupid)« (MP3, Jan. 2003) [Mardi Gras] [http://huizen.ddsw.nl/bewoners/slopera/peace/oliedom.htm].

Kitusai [Frankreich]: "L'amiral« (MP3, März 2003) [Alternative] [http://www. kitusai.com].

Lenny Kravitz \& Karem Al Sahir: »We Want Peace« (MP3, März 2003) [Rock] [http://www.rockthevote.org].

Jim Lesses [Australien]: »No Blood For Oil« (MP3, Feb. 2003) [Folk] [http://www. jimlesses.com/jimlesses.html].

Life [von Phi Life Cypher] [UK]: »Bush And Blair« (12", Feb. 2003) [HipHop] [http://www.zebratraffic.co.uk; http://www.peace-not-war.org/Music/Life/ index.html].

Lifeboat 14 [Australien]: »Dove Of Peace« (MP3, März 2003) [Christian Pop] [http://www.eternitymusic.com.au].

Live: "What Are We Fighting For " (MP3, live 26.3.2003) [Pop] [http://www. fansoflive.com/newsongs; http://clockwise.fh2.rbftpnetworks.com/archives/ 00000033.html].

Little Big Men [Schweiz]: »Mr Bush, You Are Not The President Of This World (Original / Mo'Bass Remix) (MP3, März 2003) [A Capella-Band] [http://www. littlebigmen.ch/news; http://www.databass.ch].

Maladjusted [Australien]: »iraq is burning, bagdad is in flames (MP3, März 2003) [Alternative] [http://www.mp3.com.au/track.asp?id=42411\#].

George Mann \& Julius Margolin: "Dead« (MP3, April 2003) [Folk] [http:// georgemann.home.att.net/deadiraqis.html].

John McCutcheon: »Duct Tape« (MP3, Feb. 2003) [Folk] [http://www.folkmusic. com/t_mp3.htm].

Marcus McDonald: »Named \& Shamed« (MP3, März 2003) [Folk] [http://www. mywoollyhat.com/music.asp].

MC Frontalot: "Special Delivery« (MP3, März 2003) [Rap] [http://www. frontalot.com].

Hermione \& Clive McKinley: »We Want Peace« (MP3, März 2003) [R'n'B] [http:// www.peace-not-war.org/Music/Hermione/index.html].

Mister Bogus feat. Jesse Jackson, Tony Benn, MIC Concise \& Emminemmylou: »The People's Prayer« (MP3, März 2003) [HipHop] [http://www.misterbogus.com/ nowar.php].

John Mellenkamp: »To Washington « (MP3, Feb. 2003) [Country] [http://www. mellencamp.com].

George Michael [UK]: »The Grave« (MP3, Feb. 2003) [Don McLean Cover] [http:// www.georgemichael.co.uk].

Mokai: »World Without War« (MP3, März 2003) [Acoustic Pop] [http://www. mokaimusic.com/www.html].

Molotov [Mexiko]: »Frijolero« [Bean Picker] (CD Dance And Dense Denso / Video, Feb. 2003) [Rap] [http://www.rocknespanol.com/molotov/video; http://www. molotov.com.mx/english/home.html].

Fescennine Newborne: »The Rape Of America (G Dub Mix)« (MP3, Jan.-März 2003) [Dub mit Doku] [http://artists.iuma.com/IUMA/Bands/FESCENNINE_NEWBORNE].

The Newz [Australien]: »No More War« (MP3, März 2003) [Pop] [http://www. perfactmind. .de/index. php4?menu=3\&cat $=5 \&$ tid $=140]$.

Panjabi MC feat. Jay-Z: »Beware Of The Boys« (Single-CD, März 2003) [HipHop].

Papa Dish: »The Ballad Of John Ashcroft« / »Who's Gonna Pay The Bill?« (MP3, März 2003) [Folk] [http://www.papadish.com]. 
Mike Park: »No War (MP3, März 2003) [Acoustic] [http://asianmanrecords.com/ mp3s/MikePark-032303-No_War.mp3].

The Peasants: „Take 'Em Out« (MP3, Jan. 2003) [Rock] [http://www.sonicyouth. com/prmp3/TakeEmOut.mp3; http://www.thepeasants.net].

Le Peuple de l'herbe [Frankreich]: »Chienne2Guerre« (MP3, Jan. 2003) [Freestyle] [http://www.lepeupledelherbe.net/sons.html].

Polarity/1: »Seventy Virgins (MP3, Jan.-März 2003) [Alternative Rock] [http:// www.polarity1.com/fcfree.html; http://www. polarity1.com/70virgin.html].

Cat Power: »Maybe Not« (CD You Are Free, 18.2.2003) [Folk] [http://www. sonicyouth.com/prmp3/Maybe_Not.mp3].

Protesta [Belgien]: »American Dream« (MP3, Jan.-März 2003) [Techno] [http:// www.fwf.levillage.org/protesta.htm].

Public Enemy: "Son Of A Bush« (CD Revolverlution, Juli 2002) [HipHop].

Ranto Boko [Rhodesien]: »War« (MP3, Feb. 2003) [Reggae] [http://www.bumbanet. de/music/sound/index.shtml; http://www.jujurecords.com/download.html].

Lou Reed with 7 Aurelius: »Walk On The Wild Side (Georgie Joins The Army)« (2003 Version) (MP3, April 2003) [Pop] [http://www.loureed.com/new/index_lou. html].

Mitch Renkow: »Hello Old Friend (MP3, März 2003) [Folk] [http://www. offtheroadband.com/oldFriend.html].

R.E.M.: »The Final Straw« (rough mix) (MP3, März 2003) [Pop] [http://www.remhq. com/finalStraw/finalstraw.html].

Molly Ringworm: »Iraq Attack 2003« (MP3, Jan. 2003) [Grindcore] [http://artists. $\mathrm{mp} 3 \mathrm{~s}$. com/artists/161/molly_ringworm.html].

Rivas: »Don't Let Da People Down« (MP3, März 2003) [Reggae-Pop] [http://www. colinrivas.net/pages/3/index.htm; http://www.dontletdapeopledown.com].

Rojo y Negro: "Our Government's At War $/$ "The State Of Freedom« (MP3, Feb. 2003) [Punk] [http://rojoynegro.punkunderground.org].

Adam Ryan: »Lessons Of History« (MP3, März 2003) [Folk] [http://www.indymedia. org/front.php3?article_id=310606].

Sabena Boys against the War: »Baghdad Blues« (MP3, März 2003) [Pop] [http:// polsong.gcal.ac.uk/itemaudio/baghdad_blues.mp3].

Sage Francis: »Hey Bobby« (Dirty/Clean) (MP3, März 2003) [HipHop] [http:// www.non-prophets.com/home].

Scaven: »Ravers Against War « (Techno Mix / Weird Mix) (MP3, März 2003) [Electronic mit Bush-Doku] [http://www.indymedia.nl/media/2003/03/10478.mp3].

Peggy Seeger: "The Cavemen« (MP3, März 2003) [Folk] [http://crixa.com/muse/ unionsong/u172.html; http://www.pegseeger.com].

Seer \& Shashamani All Stars: "No War For Oil« (MP3, März 2003) [Dub] [http://www.shashamani.co.uk/wfo/wfo.shtml; http://www.ampcast.com/ music/11310/artist.php].

Sergent Garcia feat. Bionik [Frankreich]: "Stop Da War" (MP3, Feb. 2003) [Crossover/Afro-Cuban] [http://www.labels.tm.fr/stopdawar].

SHT musik [Spanien]: »Iraq Attack - As Clear As Mud« (MP3, März 2003) [Folk] [http://artists.iuma.com/IUMA/Bands/SHT_musik].

Anthea Sidiropoulos [Australien]: »A Better World For You« (MP3, Feb. 2003) [Folk] [http://www.anthea.com.au/abetterworldforyou.html].

Soylent Gringo: "Let's Start A War« (MP3/Video, Jan. 2003; CD Antifuture, 2003) [Rock] [http://www.soylentgringo.com/antimusic.htm].

Spunky Munkey: »War Is Coming (MP3, Feb. 2003) [BritPop] [http://artists.mp3s. com/artists/18/spunky_monkey.html]. 
Mickey Starr: »Jets Into Baghdad« (MP3, März 2003) [Rock] [http://polsong.gcal. ac.uk/itemaudio/JetsIntoBaghdad.mp3].

Statik feat. Konflik \& Nastee: „War« (MP3, Feb. 2003) [HipHop mit Doku] [http:// statikmusic.com].

Mike Stout: »Not In Our Name« (MP3, Jan. 2003) [Rock] [http://www. mikestoutmusic.com/notinourname.ivnu].

Supaclean: "Beat The Bushes / "Go Home And Watch The War! / "Oil Change / »We're Not Gonna Go To War (MP3, März 2003) [Rock mit Doku] [http://www. bumpsy.org].

System of a Down: »Boom!« (Video, März 2003) [Rock] [http://soad.hay.am/ index.php; http://www.systemofadown.com/montage.html].

Take Aim [Neeseeland]: »The George W. Bush Track « (MP3, März 2003) [Electronic mit Doku] [http://www.amplifier.co.nz/amp/playwin?item_id=5989].

TEK [Frankreich]: »Flying Low« (MP3, März 2003) [Alternative] [http://www. kitusai.com].

Terminale X [Italien]: »ll disertore« (MP3, März 2003) [Techno-Rap] [http://buslhd. planet-d.net/tx].

Jim Terr: »A Message From Jesus (>Don't Blame It On Me<)《 (MP3, Jan.-März 2003) [Satire] [http://www. bluecanyonproductions.com/lyrics.html].

This Side of Sanity: »Bone Yard Parade (Peace Song)« (MP3, März 2003) [Pop] [http://www.thissideofsanity.com/music/peace.html].

Richard Thompson: "Outside Of The Inside (2002; CD The Old Kit Bag, Feb. 2003) [Folk Rock] [http://www.richardthompson-music.com].

Tom Zé [Brasilien]: »Companheiro Bush« (MP3, März 2003) [Latin] [http://portal. trama.com.br/portal/noticia/templnoticia.jsp?idnot=1242].

turnerprizefreakshow [UK]: »Don't Attack Iraq《 (MP3, Jan.-März 2003) [Indie] [http://artists.iuma.com/IUMA/Bands/turnerprizefreakshow].

TV Smith: »Not In My Name« (MP3, März 2003) [Acoustic Pop] [http://tvsmith.com/ NotInMyName.php].

The Unchartables: »Iraqi Lullaby« / »Please Don't Drop The Bomb On My Boyfriend / »The People In Your Neighborhood« (CD War \& Pieces, März 2003) [?Political Humor ‘] [http://www.bushoncrack.com/bocmerch/index.cfm].

Uncle Ted's Garage: »DubAmerika« (MP3, März 2003) [Folk Rock mit Doku] [http:// home.pacifier.com/ tbulger/dubamerika/dubindex.html].

Various Artists (Fredwreck Presents The S.T.O.P. Movement ft. Everlast, Trey Deee, Defari, J-Ro RBX, Daz, Soopafly, Bad Azz, WC, Dilated Peoples, The Mac Minister): "Down Wit U.S. (Dirty/Clean) (MP3, April 2003) [HipHop] [http:// www.dpgrecordz.com/fredwreck].

Various Artists (UBO): »Raise Your Hands High... Say Not In Our Name« (Single-CD, März 2003) [HipHop] [http://www.ubo.com/view_product.cfm?content_id=290; http://rap.about.com/gi/dynamic/offsite.htm?site=http://ubo.com/view_prod uct.cfm?content_id=290].

Various Artists: Hope (CD; 21.4.2003) (Benefiting the War Child charity for their specific work in Iraq).

Tracks: Travis: »The Beautiful Occupation «, Avril Lavigne: »Knockin' On Heaven's Door «, Paul McCartney: »Calico Skies«, David Bowie: »Everyone Says Hi (Metro Mix«, George Michael: »The Grave«, Ronan Keating: »In the Ghetto«, Lee Ryan [von Blue]: "Stand Up As People«, Beverley Knight: "Love's In Need Of Love Today«, Moby: »Nearer «, New Order: "Vietnam«, Basement Jaxx feat. Yellowman: »Love Is The Answer «, Spiritualized: »Hold On (War Child Mix)«, The Charlatans: »We Got To Have Peace«, Beth Orton: »O-O-H Child«, BRITS and Tom McRae: »Border Song", Billy Bragg: »The Wolf Covers Its Tracks«, Yusuf Islam [Cat Stevens]: »Peace Train«. 
Various Artists: Live Without Dead Time (CD, mixed by Dj Spooky; Beilage der Zeitschrift Adbusters, Nr. 47, Mai/Juni 2003) [http://adbusters.org/magazine/ 47/articles/live_without_dead_time.html].

Tracks: Saul Williams: »The Pledge / »Intro«, Dj Spooky: »Interlude: Journey Into Sound «, Ani DiFranco: »Coming Up«, Baghdad Live!: »Muslim Chant«, Tino: »Basic Beat«, Meat Beat Manifesto: »Dynamite Fresh «, Dj Spooky vs. DJ Goo: "That Subliminal Kid And The Last Mohican«, Negativland: »Why Is This Commercial?«, Saul Williams: »Interlude« / »Give Blood« (Dj Spooky Remix), Coldcut: "Re:volution (feat. George W. Bush)«, The (International) Noise Conspiracy: "The First Conspiracy «, Martin Luther King, Jr.: »Let Freedom Ring «, The Fire This Time: »Reluctant Warrior, Mista White: »American Psychosis (Symptom one)«, Asian Dub Foundation: »Rivers of Dub«, Dj Spooky feat. Mad Professor: "Dubtometry Interlude«, EBN: "State Extension«, Intrinsic Sky Sound System: "Vajra Kilaya Mix«, Matthew Herbert: "Starbucks«, Malcolm X \& Mario Savio: »Various Excerpts«, Michael Franti \& Spearhead: »Rock The Nation (The Dawning)«, El-P: »Deep Space - 9mm«, Public Enemy: »Revolverlution«, J-Live: "Satisfied?«, Honey Barbara: »Famous Animal«, Mad Professor: »Asylum Of Dub«, Alter Echo: »As Yet Untitled«, Bad Brains: »Leaving Babylon«, Sun Ra \& His Arkestra: »Nuclear War «, Stephan Smith: »New World Order«, Allen Ginsberg: »End The Vietnam War ( $\mathrm{Dj}$ Spooky Remix), illyB: »Drums And Breakbeats«, Fugazi: »Pink Frosty Demo«, King Britt feat. Ursula Rucker: »Human Beings Want To Be Happy«.

Various Artists [Australien]: No Blood For Oil (CD, März 2003) (Benefiting the campaign against the war on Iraq) [http://www.indie-cds.com/main.htm].

Tracks: Shane Pullen: »Oh My God«, The Hottentots: »Graceful«, Peter Hicks: "Faces In The Dark«, Mathew Wooley: "A Flash and A Bang «, Julie Levy: "Survivors«, Ian Paulin: »Peace In Our Time«, The PeaceKnickers String Band: "Sail Away Ladies «, Free Spirit Placenta: »| Know Now«, Niall Fenix: "All For Love«, Bernard Carney: "War Song«, Jan Perigo: »Peace Is The Way«, Mike Raine: "There Is No Time«, John Hughes: »Double Speak«, Tasmanian Grass Roots Union Choir: »Oh No John«, Bruce Watson: »Nobody Should Have To Go Through This«, John Warner: »International Cowboy«, Jim Lesses: »No Blood For Oil«, Anthea Sidiropoulos: »A Better World For You«, Paul Chalson with Sabri Samson: »The Weaving «, Duncan Chalmers: »Advise Australia Fair«.

Various Artists: Peace Songs (A benefit album to help children affected by war) (Doppel-CD, Kanada 21.4.2003) [http://sonymusic.ca/PeaceSongs].

Tracks: Avril Lavigne: "Knockin' On Heaven's Door «, Chantal Kreviazuk: "Redemption Song «, Jarvis Church feat. K'naan: »One«, k-os: »Livin' In A World Corrupt«, Kyprios: "Stand Up«, G. Love \& Graph Nobel: »Love«, David Usher with My Brilliant Beast: »If You Tolerate This «, David Bowie: »Everyone Says Hi (Metro Mix)«, The Charlatans: »We Gotta Have Peace«, In Essence: »Change Is Gonna Come«, Beth Orton: »Ooh Child«, Our Lady Peace: »Imagine«, Tom McRae: »Border Song «, Spiritualized: »Hold On (War Child Mix) «, Basement Jaxx feat. Yellowman: "Love Is The Answer «, Moby: "Nearer «, Yusef Islam [Cat Stevens]: »Peace Train«, Jann Arden: »Fighting For The World«, Bryan Adams: "Don't Drop That Bomb On Me«, Bruce Cockburn: "It's Going Down Slow«, Paul McCartney: "Calico Skies«, Gord Downie \& the Country of Miracles: »If I Had A Hammer «, Liam Titcomb: »War «, Elvis Costello \& the Imposters: »Everybody's Crying Mercy«, Leonard Cohen: »Anthem«, Barenaked Ladies: »Lovers In A Dangerous Time (Live)«, Garou: "Le monde est stone (Live)«, Celine Dion: "Prayer «, Eurythmics: "| Saved The World Today«, Travis: "The Beautiful Occupation«, Billy Bragg: »The Wolf Covers Its Tracks«.

Various Artists: SALT In The Wound (Triple AAA Single for the Protest Vote, März 2003) [http://www.stopwar.org.uk/release.asp?id=090303].

Tracks: Carpet Bombers for Peace feat. Jello Biafra as The Cowboy President 
from Hell: »Allah Save Queens«, Change: »We Want A Ceasefire«, Conflict: »A Gaping Hole«.

Visionary Underground [UK]: »Countries At War (ft MC TC Izlam \& $\mathrm{Dr}$ Das/ADF) (MP3, März 2003) [D'n'B/HipHop] [http://www.visionaryunderground.com/html/ audio.html].

VSOP [Holland]: »Machteloos« (MP3, März 2003) [HipHop] [http://www.vsopxo. com/download.htm].

Rhonda Walsh: »No Blood For Oil« (CD Imagine, Jan.-März 2003) [Folk] [http:// www.cdbaby.com/cd/rhondawalsh].

John Warner [Australien]: "Coalition Of The Willing / »International Cowboy (MP3, Feb.2003) [Folk] [http://www.crixa.com/muse/unionsong/u168.html].

Bruce Watson [Australien]: »Nobody Should Have To Go Through This« (MP3, Feb. 2003) [Folk Rock] [http://crixa.com/muse/unionsong/u180.html].

Watters \& Daughters: "We Will Send Our Sons No More« (MP3, März 2003) [Pop] [http://www.mhonline.net/ londam].

Saul Williams: »No Man's Land« (MP3, live Feb. 2003) [Freestyle] [http://www. notinournamemusic.com/home.php].

Saul Williams: »The Pledge (Dj Spooky Parallax View Mix)« (MP3, März 2003) [Spoken with Beats] [http://www.synchronicrecords.com/sound/pledge_plax.mp3].

John Williamson [Australien]: »Keep Australia Beautiful (Single-CD, Feb. 2003) [Folk] [http://www.johnwilliamson.com.au/music/keep_oz_beautiful.html].

Workgroup 3.1: »Iraq Attack« (MP3, März 2003) [Electronic mit Doku] [http:// artists.iuma.com/IUMA/Bands/Workgroup_3.1].

World Peace Clowns: »American« (MP3, Feb. 2003) [Acoustic] [http://www. clownism.com/index.html].

The Youvees: »Why O Why Must We Attack Iraq« (MP3, Feb. 2003) [Pop] [http:// www.iraqsong.com/index.html].

Yusuf Islam [Cat Stevens]: »Peace Train« (MP3, Feb. 2003) [Pop] [http://www. yusufislam.org.uk/articlepeacetrain.htm].

Zack de la Rocha \& DJ Shadow: »March Of Death « (MP3, März 2003) [HipHop/Trash] [http://www.zackdelarocha.com].

Zamboni Dave [Kanada]: »The Peace Song « (MP3, Jan.-März 2003) [Parodie Stompin' Tom Connor: »The Hockey Song«] [http://www.jameslove.com/funstuff_22. htm; http://members.shaw.ca/zamboni_baloney].

Zearle: "No Death In Iraq! « (MP3, März 2003) [HipHop] [http://www.garageband. com/artist/Zearle; http://artists.iuma.com/IUMA/Bands/Zearle].

Roy Zimmerman: "Saddam Shame (Revised Version)" (MP3, März 2003) [Folk] [http://www.roysongs.com/lyrics/foremen/folkmetaphor/saddam.htm].

\subsection{Anti War MP3-(Link-)Sammlungen}

Anti-War In Iraq Music (rund 20 MP3s, März-April 2003) [http://www. onlisareinsradar.com/archives/antiwar_in_iraq_music/index.php].

Anti-War Songs (über 70 MP3s, März-April 2003) [http://onegoodmove.org/1gm/ 1gmarchive/000628.html].

Anti War Songs, à la Carte (Datenbank mit Links zu legalen Downloads und Lyrics) [http://www.lacarte.org/songs/anti-war].

Music Against The War - Overview And Links (über 110 MP3s, März-April 2003) [http://belgium.indymedia.org/news/2003/04/58267.php].

No War In Iraq - Piccolo Network Contro La Guerra [Italien] (über 20 MP3s, März 2003) [http://www.syncprodz.net/nowariniraq]. 
Peace Not War - More Anti-War Music (rund 30 MP3s, April-Mai 2003) [http://www.peace-not-war.org/Music/index.html].

Protest Records (über 70 MP3s, März-April 2003) [http://www.protest-records. com/mp3/index.html].

Resist War (über 20 MP3s, März-April 2003) [http://www.resistwar.com/other_ music.htm].

\subsection{Songs aus der BRD und Österreich}

A-Broo: »America (MP3, März 2003) [HipHop] [http://www.battledrones.de; http: / / www.songdb.de/index.php?page=song\&tid=155883].

Acme Mc: »Game« (MP3, März 2003) [HipHop] [http://www.derdave.de/rokz58/ acme\%20mc-game.mp3].

Becks: »Krieg (MP3, 26.3.2003) [HipHop] [http://www.fmn-music.com; http:// www.freeman.de.am; http://members.webbeatz.de/FMN-Music].

BEN: »Sturm kommt auf (MP3, Mai 2003) [Pop] [http://www.pro-ben.de].

Bernd, Jürgen und Charlie [Neuwieder Musiker]: "Nie wieder Krieg! (MP3, Feb. 2003) [Rock] [http://www.eirene.org/news-template/news.irak-lokal.2/index. html].

Bernhard Nikitka: »Krieg “ (MP3, März 2003) [Christl. Pop] [http://www.songtext. net/de/mp3_download.php?id=4498; http://www.nikitka.de/start.htm].

Blindmatic: "Stop The War« (MP3, März 2003) [Electro-ClickHop-Downbeat] [http://www.arizona.indymedia.org/news/2003/03/8756.php].

Blumentopf [Österreich]: »Danke Bush« (MP3, März 2003) [HipHop] [http:// blumentopf.netline.de].

Bolly F: »No War - Krieg auf keinen Fall« (MP3, März 2003) [Dt. Schlager] [http://www.songtext.net; http://hometown.aol.de/devils6367/index.html].

CODX: »KRIEG KEIN FRIEDEN« (MP3, März 2003) [HipHop] [http://www.codx.info].

Curse: »Hand hoch« (CD Innere Sicherheit, März 2003) [HipHop] [http://www. curse.de].

DAF (Deutsch Amerikanische Freundschaft): »Der Sheriff - Anti-Amerikanisches Lied« (CD-Single/Video und CD 15 Neue DAF Songs, Feb. 2003) [Techno-Pop] [http://www.daf.ag].

Delta (Tonic \& Ton): »Zur Irakkrise« (MP3, März 2003) [HipHop] [http://home.tonline.de/home/vangoens/delta-zuderirakkrise.mp3].

Die Controverse [Österreich]: »Präventiv töten« (MP3, Jan.-Feb. 2003) [HipHop] [http://www.controverse.net/praeventiv.html].

Die Quadratkatzen: »Wir sind gegen Krieg« (MP3, 14.2.2003) [Pop] [http://www2. $\mathrm{mp} 3$.de/musik/bands/de/2/99513?param = ] .

DJ Hype feat. Akrobatik \& Zion: "We're At War« (MP3/CD 1973*Recon; März 2003) [HipHop] [http://www.beatzausderbude.de; http://www.djhype.de/1973/war. $\mathrm{mp} 3$.

DJ NBK and Friends: If You Wanna Stop Terrorism Start With The US Imperialism (MP3-CD, Feb. 2003) [HipHop] [http://213.133.99.3/theben/imperialism.zip; http://www.theben-productions.de/show.php?item=57].

Tracks: Debil: »Antikrieger« (exclusive!), Dead Prez: »Know Your Enemy«, Don Martin: »Mayday« (exclusive!); 4. Casual Brothers: »Decleration Of Motivation«, Dilated Peoples: "War «, Denksport feat. Rainer von Vielen: "Visionen« (exclusive!), Promoe: »Stay«, »Statement For Peace«.

Dj Sunny XXs: »No War!!!« (Krieg gegen IRAK RMX) (MP3, 22.3.2003) [Trance] [http://www2.mp3.de/musik/bands/de/2/191343?param=|]. 
Do The War-Stop!!!: »DoTheWar-Stop!« (MP3, 20.3.2003) [Power-Pop] [http:// www2.mp3.de/musik/bands/de/1/198553?param =20 |59\&SID=cd511a0d09b216d 06a9daf76a1c4ef2e].

Dreher: »Seitdem herrscht Krieg« (MP3, März 2003) [HipHop mit Doku] [http:// forum.rap.de/forum/showthread.php?s=2002e2146381b94bee9827f42ee0a62d\&t hreadid=18499; http: / /www.8ung.at/dreher/seitdem_herrscht_krieg_b-.mp3].

Extrabreit: »Öl!« (MP3, Feb. 2003) [Deutsch-Rock] [http://www.die-breiten.de].

Falken-Friedens-Kooperative: »Frieden « (MP3, Jan.-März 2003) [Rock] [http:// jusos-hiddenhausen.de; http://jusos-hiddenhausen.de/mp3/frieden.mp3].

Fury in the Slaughterhouse: "Crusaders Of Gasoline (MP3, April 2003) [Folk Rock] [http://www.spv.de/furyintheslaughterhouse/default.html].

Fuxx \& Ritman: »Dissneyland (Antikriegssong)« (MP3, März 2003) [HipHop] [http:// www.ritman.de/website/intern/html/brb.html].

>Georg W. Busch< [Österreich]: »Die Achse des Bösen« (MP3, März 2003) [A-Rock] [http://www.xenia.at/Achse\%20des\%20Bösen\%201.pdf].

Guildo Horn: »Ein bisschen Frieden« (MP3, Feb. 2003) [Dt. Schlager] [http://www. guildo-horn.de/aktuell.htm; http://www.guildo-online.com].

Hidden Nation Crew [Österreich]: »Bomben« (MP3, März 2003) [HipHop] [http:// www.stiege44.com/hnc/hnc.htm].

Icklack Squad: »Kriegsberichterstatter (LP-Tape Aktion Mutante, Feb. 2003) [HipHop] [http://www.hiphop.de/de/home.cfm?viewfile=1\&fn=77080AF97D6D\&mod $=$ get\&CFID=305314].

Igor K: »F-k USA《 (MP3, Jan. 2003) [HipHop] [http://mp3.de/igorkr].

Igor K: »22. März 2003« (MP3, 25.3.2003) [Doku München 22.3.03] [mp3.de/igorkr].

Iriepathie [Österreich]: »Mehr Fragen als Antworten« (MP3, März 2003) [HipHop] [http://www.iriepathie.com].

Jack Orsen: »Weltkrieg No 3《 (MP3, Feb.-März 2003) [HipHop] [http://www. royalbunker.de/download].

Lato: »Not In My Name! (MP3, März 2003) [Acoustic Pop] [http://www.6x0.ideia. de/list.htm; http://www.ourhouseberlin.de].

Livepräsenz Crew [Südtirol]: »Krieg und Frieden« (MP3, 6.5.2003) [HipHop] [http:// www.lpz.rocks.it; http://www.webbeatz.de/Members/livepraesenz-main.php].

Madforce: "Stop The War« (MP3, März 2003) [HipHop] [http://www. madforcehiphop.com].

Marius Müller-Westernhagen: »Frieden« (Single Krieg, 1992; als MP3-Download ab 20.3. 2003) [Pop] [http://www.westernhagen.de].

Massendefekt: »Den nächsten Krieg gewinnt der Tod« (MP3, März 2003) [Punk] [http://www.massendefekt.com; http://www.bundespunk.de].

Mellow Mark: »Weltweit « (MP3, März 2003) [Rap] [http://www.mellowmark.de; http://www.rap.de/records/mellowmark/mellowmark_weltweit.mp3].

Michel Montecrossa: »Friedens Rock« (RealPlayer/Video, live März 2003) [’Cyberrock ‘] [http://www.mirapuri-enterprises.com/Michel-Newsletter/\#video].

Mnemonic: »Momentaufnahme 23.03.03« (MP3, März 2003) [HipHop] [http://www. beatzausderbude.de/media/audio/mnemonicmomentaufnahmen230303.mp3].

Mobla aka Base Unit: »Apocalypse Now « (RealPlayer, 27.5.2003) [HipHop] [http:// www.webbeatz.de/Members/mobla-main.htm; http://www.mobla.net].

NachtBarschaft: »Krieg" (RealPlayer, 5.4.2003) [HipHop] [http://www.webbeatz. de/Members/nachtbarschaft-main.php].

Nesti: »Und mal wieder...« (MP3, März 2003) [HipHop] [http://www.nestionline.de; http://www.lacosamia.de/nesti/news.html].

Nuemmes: "George Bush: We will stop you! (MP3, Feb. 2003) [Parodie Queen: »We Will Rock You«] [http://www.nuemmes.de/songs/texte/we-will-stop-you.html]. 
Nuemmes: »Inspekteure in die USA! « (MP3, April 2003) [Melodie >Zieht den Bayern die Lederhosen aus ‘] [http://www.nuemmes.de/werkstatt/inspekteure.shtml].

Peaceworkers: "Stop The War From Starting " (Single-CD, März 2003) [Pop] [http://www.a45music.de/kuenstler/p_t/peaceworkers.htm].

Peter Lohmeyer \& Fink mit Ulrich Tukur: »Bagdad Blues« (Single-CD, 17.2.2003) [Country-Pop] [http://www.bagdadblues.de].

Pierre \& Michael (von DING.TV): »No More No War Songs « (MP3/Video, März 2003) [Acoustic] [http://www.dasding.de/images/headlines/blau_tuerkis/gfx/hoeren_ mp3.gif; http://www.dasding.de/themen/dingtv].

Premium Style: »Hoffnung “ (MP3, März 2003) [HipHop] [http://www.premiumstyle. de].

Pyranja: „Glauben« (MP3, März 2003) [HipHop] [http://www.pyranja.net].

Recupforce: »Amerika« (RealPlayer, 5.3.2002) [HipHop] [http://www.webbeatz. de/Members/recup-main.htm].

Rekobo: "Geschichte wird geschrieben« (MP3, März 2003) [HipHop] [http://www. rapstuff.de/rek/geschichte.mp3].

Robda: "Krisenherd« (RealPlayer, 5.5.2003) [HipHop] [http://www.robda.de; http://www.webbeatz.de/Members/robda-main.php].

Roof Club feat. Songtext.net: »We Need Peace Now« (MP3, April 2003) [Pop] [http: //www.songtext.net].

SIM \& Spynx [Österreich]: »Krieg für die Wahrheit« (MP3, März 2003) [HipHop] [http://www.rapmusic.at/SIM].

Sir Lion: »Pray Before You Fight« (MP3, März 2003) [Techno-Pop] [http://arizona. indymedia.org/news/2003/03/8444.php; http://stage.vitaminic.de/main/mr. bullfish/all_tracks].

Solid feat. das W.I.R., Double U \& Hank: "Schrei!« (MP3, 3.4.2003) [HipHop-Hardcore] [mp3.de/das_wir; http://www.solid-band.de].

Spax: "Kriegstagebuch« (Single-CD/Video, März 2003) [HipHop] [http://spax. mindspray.de/kriegstagebuch/main.php].

Subway to Sally: »Falscher Heiland (Maxi-CD, 10.3.2003) [Rock] [http://www. homomagi.de/subway_to_sally_falscher_heiland.htm]

Super Zwei: »Georgie (RealPlayer, März 2003) [Pop] [http://www.superzwei.de].

Tagträumer feat. Aynur: »Living In A Perfect World (Mükemmel Dünya Için)« (Single-CD/Live-Video, Feb. 2003) [Pop] [http://www.tagtraeumer.com; http:// www.ndrtv.de/grandprix/images/btn_video.gif].

T BurnA: »Bombenteppich« (RealPlayer, 9.5.2003) [HipHop] [http://www. webbeatz.de/Members/tburna-main.php].

Themanwho \& Supernuss: »Morgen Kinder (No war in Iraq!)« (MP3, Feb.-März 2003) [Parodie »Morgen, Kinder...«] [http://mp3.de/themanwho].

The Punkles: »Ha Ha Ha (Make Laugh Not War) (MP3, Jan.-März 2003) [Punk] [http://www.punkles.com: The Punkles' anti war song].

Tiefenrausch feat. Da Invidious Rebel \& DJ Krille: »Schwarzes Blut« (CD Urknall aus der Tiefe, März 2003) [HipHop] [http: //www.tiefenrausch-rap.de.vu].

Toni-L (Ex-Advanced Chemistry): »Zerbombte Zukunft« (MP3, März 2003) [HipHop] [www.toni-l.de].

Triple-B: »No War On Iraq« (MP3, Jan.-März 2003) [HipHop] [http://www.no-waron-iraq.tk].

Twisted feat. Nina Maleika Lorenz: »Millionen weiße Tauben werden bluten (wenn ihr weiterschießt)« (MP3, März 2003) [HipHop] [http://www.allesreal.de/mag. php?site=news_old; http://erlendkrauser.de/Millionen_weisse_Tauben.mp3]. 
Versbox: »Minenfalle« (CD Koyaanisqatsi, März 2003) [HipHop] [http://versbox. info/vers.box/musik/koyaanisqatsi; http://versbox.info/vers.box/texte?show= minenfalle].

Versinfarkt: »Und ich weiß nichts « (MP3, März 2003) [HipHop] [http://www. raps4heads.de/main.htm].

W: »Mr. President« (MP3, März 2003) [Dancehall] [http://www.droen.de; http:// www.dub-ill-you.de].

Wolf \& Gang: »Mon A®mi« (RealAudio, 20.3.2003) [Pop] [http://www.bairischesprache.de/ramadan.html].

Zugga \& Eisblume: »Antikriegsdemo« (MP3, Feb. 2003) [HipHop] [http://www. zuggaundeisblume.de].

\section{Nachklänge}

Anti-Flag: »Operation Iraqi Liberation (O.I.L.)« (CD The Terror State, Okt. 2003) [Punk].

Beastie Boys: "An Open Letter To NYC « (CD To The Five Boroughs, Juni 2004).

Black Eyed Peas feat. Justin Timberlake: "Where Is The Love? (Maxi-Single, Juli 2003; CD Elephunk, Sept. 2003) [HipHop].

Country Joe \& The Fish: »Cakewalk To Baghdad« (RealAudio, live April 2004) [Folk] [http://www.countryjoe.com/cjb.htm].

Robert Cray: »Survivor « (CD Time Will Tell, Juli 2003) [Blues].

Doc Jazz: "Down Down Dubya (MP3, Juni 2004) [Folk Rock mit Bush-O-Tönen] [http://polsong.gcal.ac.uk/songs/jazz2.html].

John Fogerty: »Déjà Vu (All Over Again)« (Single-CD, Juli 2004) [Pop] [http://www. johnfogerty.com/main.php].

Merle Haggard: »That's The News« (Single-CD, Juli 2003; CD Haggard Like Never Before, Sept. 2003) [Country].

Immortal Technique: »The Cause Of Death $/$ / The Fourth Branch« (CD Revolutionary Vol. 2, Okt. 2003) [HipHop].

Reinhard Mey: »Alles O.K. in Guantanamo Bay« (CD Nanga Parbat, Mai 2004) [Liedermacher].

Willie Nelson: »What Ever Happened To Peace On Earth« (Live, 3.1.2004) [Ballad].

N.E.R.D.: »Drill Sergeant « (CD Fly Or Die, März 2004) [Rock].

Radiohead: $» 2+2=5$ « (CD Hail To The Thief, Juni 2003) [Rock].

David Rovics: „The War Is Over« (komp. Mai 2003) / »Operation Iraqi Liberationc (komp. Juli 2003) (MP3-CD Who Would Jesus Bomb?, 2003) [Folk] [http://www. davidrovics.com; http: / /www.soundclick.com/pro/?BandID=111310].

Sonic Youth: »Peace Attack « (CD Sonic Nurse, Juni 2004) [Noise Rock].

Various Artists: What About Us? (A Hip-Hop compilation that sets out to expose the consequences of war and how it affects our communities, Dez. 2003) [http:// www.hardknockrecords.com].

Tracks: Davey D: »Intro«, Rico Pabon \& DJ Riddm: »Yo Naci«, The Piper: »U.S. History«, The Frontline: »'m Still Livin'«, Dro Golden: »Maybe If I Was Blind«, Raashan Ahmad [von Crown City Rockers]: »We Can«, Cool Nutz feat. Bosko: "Where Will They Go?«, Lunar Heights: »Lickshot!«, Barbara Lee: »Interlude«, Blackalicious: "Sky Is Falling «, Michael Franti \& Spearhead: »Bomb The World«, Bukue One: »Work Itself Out«, Shing02 \& Doc Maxwell: »Doxology«, Zion I: »Dune«, Non Prophets: »Hey Bobby«, Hobo Junction: »Blame Everybody«, Ome: »The Ship Off «, Abstract Tribe U: »Rapcha'«. 